\title{
FATOR DE CRESCIMENTO SEMELHANTE À INSULINA-I (IGF-I) EM BEZERROS RECÉM-NASCIDOS ALEITADOS COM COLOSTRO DE VACAS TRATADAS COM rbST
}

\author{
AdRIANA REgINA BAGALDO
}

Tese apresentada à Escola Superior de Agricultura "Luiz de Queiroz", Universidade de São Paulo, para obtenção do título de Doutor em Agronomia, Área de Concentração: Ciência Animal e Pastagens.

PIR A C I C A B A

Estado de São Paulo - Brasil

Setembro - 2004 


\title{
FATOR DE CRESCIMENTO SEMELHANTE À INSULINA-I (IGF-I) EM BEZERROS RECÉM-NASCIDOS ALEITADOS COM COLOSTRO DE VACAS TRATADAS COM rbST
}

\author{
AdRIANA REgINA BAGALDO \\ Zootecnista \\ Orientador: Prof. Dr. RAUL MACHADO NETO
}

Tese apresentada à Escola Superior de Agricultura "Luiz de Queiroz", Universidade de São Paulo, para obtenção do título de Doutor em Agronomia, Área de Concentração: Ciência Animal e Pastagens.

P I R A C I C A B A

Estado de São Paulo - Brasil

Setembro - 2004 


\section{Dados Internacionais de Catalogação na Publicação (CIP) DIVISÃO DE BIBLIOTECA E DOCUMENTAÇÃO - ESALQ/USP}

\section{Bagaldo, Adriana Regina}

Fator de crescimento semelhante à insulina-I (IGF-I) em bezerros recém-nascidos aleitados com colostro de vacas tratadas com rbST / Adriana Regina Bagaldo. - -

Piracicaba, 2004

$82 \mathrm{p}$.

Tese (doutorado) - - Escola Superior de Agricultura Luiz de Queiroz, 2004.

Bibliografia.

1. Aleitamento animal 2. Bezerros 3. Colostro 4. Crescimento animal 5. Hormônios I Intestino delgado 6. Somatropinas recombinantes 7. Vacas I. Título

CDD 636.2

\section{"Permitida a cópia total ou parcial deste documento, desde que citada a fonte - $\mathrm{O}$ autor"}




\section{Aos meus queridos pais,}

Lázaro e Regina, pelo amor incondicional, incentivo a todo momento, compreensão e paciência devida a minha ausência desde o início da minha formação,

Ao meu irmão,

Carlos, pelo carinho e eterna amizade,

A minha avó,

Lúcia, pelo carinho, dedicação e orações em todos esses anos, 


\section{AGRADECIMENTOS}

À Escola Superior de Agricultura "Luiz de Queiroz" - USP e ao Departamento de Produção Animal, pela oportunidade de realização deste curso.

Ao CNPq pela concessão da bolsa de estudo.

Ao Prof. Dr. Raul Machado Neto, pela valiosa orientação, amizade e principalmente por acreditar em mim.

Ao Prof. Dr. Eduardo Delgado, pela amizade, ensinamentos e disposição em colaborar com este trabalho a qualquer momento.

Ao Prof. Dr. Dante P. Lanna, pelo acesso livre ao Laboratório de Crescimento Animal e pela co-orientação.

Ao Prof. Dr. Luiz Coutinho, pelo apoio e sugestões neste trabalho.

Ao Prof. Raul D'Arce, pelo sorriso e carinho com que sempre me tratou.

À minha querida amiga Patricia, pelo carinho, cumplicidade, conselhos e apoio nos meus momentos mais difíceis.

À Paula, pela amizade e disposição de ajuda a qualquer momento.

Às amigas Tuka e Ana, pela preciosa amizade que ganhei nesses anos.

À Neusa, pelo carinho e principalmente por me tratar como uma verdadeira filha. 
À minha amiga especial, Renice, pelo carinho e compreensão da minha ausência em momentos que mais precisava.

À amiga Liris, pelo sorriso sempre presente e pelo companheirismo.

Ao Marcelo, pelo carinho e compreensão pelo meu pouco tempo disponível.

A todos meus colegas de laboratório, Andréa, Liana, Marco, Rodrigo e Sergio, pelos momentos de descontração.

À Granja Leiteira Santa Rita e ao Sr. Roberto Jank Junior por permitir a realização deste trabalho.

Aos funcionários da Granja Leiteira Santa Rita, pela amizade, carinho e disposição em nos ajudar, especialmente o nosso amigo Mingo. 


\section{SUMÁRIO}

Página

LISTA DE FIGURAS........................................................................ viii

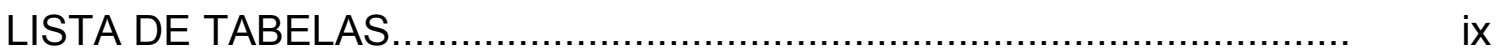

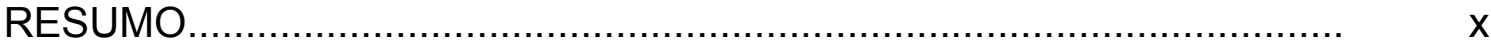

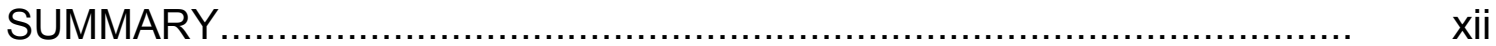

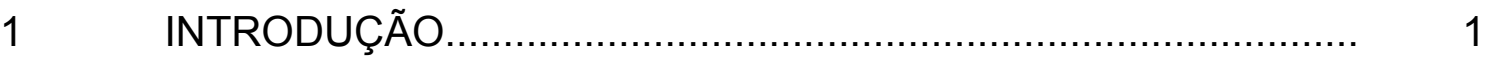

2 REVISÃO DE LITERATURA................................................... 3

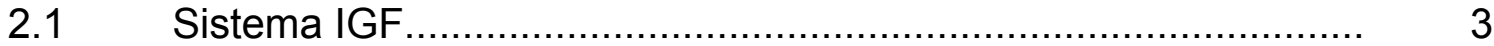

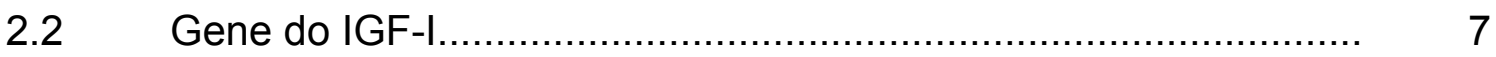

$2.3 \quad$ Gene do receptor do IGF-I (receptor tipo I).............................. 8

2.4 Localização dos receptores no trato intestinal.............................. 10

2.5 IGF-I nas secreções lácteas.................................................. 11

2.6 IGF-I e o desenvolvimento do trato intestinal.............................. 12

2.7 Efeitos sistêmicos do IGF-I exógeno........................................ 20

$3 \quad$ MATERIAL E MÉTODOS ................................................... 22

3.1 Animais e tratamentos...................................................... 22

3.2 Alimentação e manejo dos animais........................................... 23

3.3 Coleta de amostras............................................................... 23

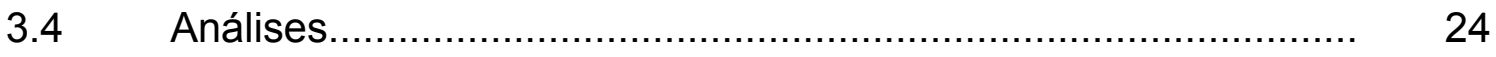

3.4.1 Quantificação do IGF-I...................................................... 24

3.4.2 Extração de RNA total............................................................... 24

3.4.3 Reação de Transcrição Reversa................................................ 25 
3.4.4 Obtenção dos "primers" ......................................................... 25

3.4.5 Otimização de condições de PCR................................................. 27

3.4.6 Clonagem das seqüências........................................................ 28

3.4.7 Extração de plasmídios........................................................ 29

3.4.8 Gene da $\beta$-actina........................................................... 30

3.4.9 Cálculos das diluições dos clones para a curva padrão do IGF-I e receptor tipo I................................................................. $\quad 32$

3.4.10 PCR em tempo real....................................................... 32

3.4.11 Cálculos da quantificação dos genes do IGF-I e receptor tipo I.... 34

3.4.12 Extração e quantificação do DNA total...................................... 34

3.4.13 Quantificação do RNA total.................................................. 35

3.4.14 Quantificação da proteína total................................................ 36

3.5 Análise estatística............................................................. 36

$4 \quad$ RESULTADOS E DISCUSSÃO............................................. 38

4.1 Concentrações de DNA, RNA e proteína no fígado e tecidos do trato intestinal na fase perinatal de desenvolvimento................... 38

4.1.1 Ingestão de colostro.............................................................. 38

4.1.2 Durante o desenvolvimento neonatal......................................... 53

4.2 Avaliação da expressão do gene do IGF-I pela abundância de

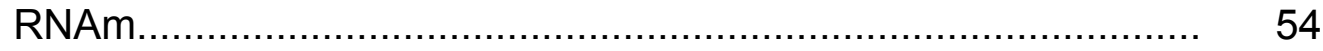

4.3 Avaliação da expressão do gene do receptor tipo I pela abundância de RNAm............................................................... 61

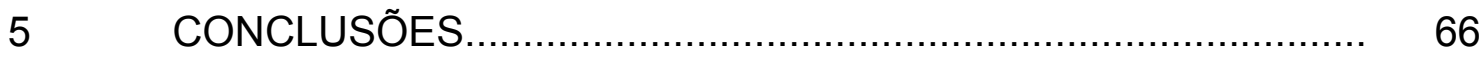

REFERÊNCIAS BIBLIOGRÁFICAS ............................................... 67 


\section{LISTA DE FIGURAS}

Página

1 Concentrações de DNA no jejuno de bezerros, em diferentes idades, que receberam colostro de vacas controle ou submetidas ao rbST, durante o período pré-parto........................................... 40

2 Concentrações de proteína no jejuno de bezerros, em diferentes idades, que receberam colostro de vacas controle ou submetidas ao rbST, durante o período pré-parto..................................................

3 Relação proteína/RNA no jejuno de bezerros, em diferentes idades, que receberam colostro de vacas controle ou submetidas ao rbST, durante o período pré-parto

4 Relação proteína/RNA no íleo de bezerros, em diferentes idades, que receberam colostro de vacas controle ou submetidas ao rbST, durante o período pré-parto

5 Relação RNA/DNA no jejuno de bezerros, em diferentes idades, que receberam colostro de vacas controle ou submetidas ao rbST, durante o período pré-parto. 


\section{LISTA DE TABELAS}

Página

1 Condições de amplificação dos genes do IGF-I e receptor tipo I no termociclador RoboCycler....................................................... 28

2 Condições de PCR em tempo real dos genes do IGF-I, receptor tipo I e $\beta$-actina utilizando-se o LightCycler.

3 Concentrações de DNA, RNA e proteína no fígado, jejuno e íleo nas diferentes idades de bezerros que receberam colostro de vacas controle e submetidas à administração de rbST durante o período pré-parto

4 Relações proteína/DNA, proteína/RNA e RNA/DNA no fígado, jejuno e íleo, nas diferentes idades de bezerros que receberam colostro de vacas controle e submetidas à administração de rbST durante o período pré-parto

5 Expressão do RNAm do IGF-I no fígado de bezerros, em diferentes idades, que receberam colostro de vacas controle ou submetidas ao rbST durante o período pré-parto.

6 Expressão do RNAm do IGF-I jejuno e íleo, nas diferentes idades de bezerros que receberam colostro de vacas controle e submetidas à administração de rbST durante o período pré-parto.

7 Expressão do RNAm do receptor tipo I no fígado, jejuno e íleo, nas diferentes idades de bezerros que receberam colostro de vacas submetidas à administração de rbST durante o período préparto 


\title{
FATOR DE CRESCIMENTO SEMELHANTE À INSULINA-I (IGF-I) EM BEZERROS RECÉM-NASCIDOS ALEITADOS COM COLOSTRO DE VACAS TRATADAS COM rbST
}

\author{
Autora: ADRIANA REGINA BAGALDO \\ Orientador: Prof. Dr. RAUL MACHADO NETO
}

\section{RESUMO}

$O$ presente trabalho teve por objetivo verificar o efeito de diferentes níveis de IGF-I no colostro de vacas que receberam rbST durante o período pré-parto, no desenvolvimento do trato intestinal e na expressão do gene do IGF-I e de seu receptor no fígado e intestino de bezerros. Quarenta e duas vacas da raça Holandesa, gestantes e multíparas foram distribuídas ao acaso em dois grupos de 21 animais, o grupo rbST que recebeu hormônio de crescimento (500 mg rbST) e o grupo controle que recebeu injeção de vitamina E. As aplicações tiveram início aos 35 dias pré-parto, em intervalos de 14 dias até a data de parição. Os bezerros recém-nascidos foram distribuídos aleatoriamente, de acordo com as seguintes idades em que foram abatidos: após o nascimento e sem a ingestão de colostro, dois e sete dias de vida com ingestão de colostro das respectivas mães. Após o abate, amostras do fígado e segmentos do intestino delgado (jejuno e íleo) foram coletadas para 
quantificação de DNA, RNA, proteína total e o RNAm do IGF-I e do receptor tipo I. O delineamento experimental utilizado foi o inteiramente casualizado, numa estrutura fatorial $2 \times 3$, correspondendo aos grupos das mães (rbST ou controle) e as idades dos bezerros (após o nascimento, dois e sete dias de vida). No fígado, as concentrações de RNA e proteína (mg/g tecido) foram maiores no segundo dia de vida e a relação proteína/RNA aumentou no sétimo dia de vida $(P<0,05)$. O jejuno apresentou interações entre os tratamentos nas concentrações de DNA, proteína e relações proteína/RNA e RNA/DNA $(P<0,05)$. Os bezerros que consumiram colostro proveniente de vacas que receberam rbST apresentaram, no jejuno, maiores concentrações de DNA no segundo dia de vida e diminuição a níveis intermediários entre nascimento e dois dias, comparados aos sete dias de vida. Este efeito também foi observado na relação proteína/RNA. No grupo controle, também se verificou aumento de DNA aos dois dias, mas não houve diferenças aos sete dias, e a relação proteína/RNA foi semelhante entre as idades. A concentração de proteína no jejuno do grupo rbST aumentou no segundo dia de vida e diminuiu no sétimo, enquanto que no grupo controle, este aumento foi verificado apenas no sétimo dia de vida. A relação RNA/DNA diminuiu apenas no grupo controle $(P<0,05)$. A expressão do gene do IGF-I foi maior ao nascimento e aos sete dias de idade no fígado dos bezerros do grupo rbST $(P<0,05)$. As concentrações do gene do receptor tipo I diminuíram com a idade dos bezerros $(P<0,05)$. Ao nascimento, 0 intestino dos bezerros apresentou condição de resposta celular à presença do IGF-I proveniente do colostro. Os resultados sugerem que as células do jejuno de bezerros do grupo rbST apresentaram um diferente estágio de maturação. 


\section{INSULIN-LIKE GROWTH FACTOR-I (IGF-I) IN NEWBORN CALVES FED COLOSTRUM OF COWS TREATED WITH rbST}

Author: ADRIANA REGINA BAGALDO

Adviser: Prof. Dr. RAUL MACHADO NETO

\section{SUMMARY}

The objective of this study was to verify the effect of different levels of IGFI in colostrum of cows treated with rbST during dry period, in the development of the intestinal tract and IGF-I and receptor gene expression in the liver and intestine of calves. Forty-two Holstein cows, in gestation and multiparous, were randomly assigned in two groups of 21 animals. Group rbST received injection of growth hormone (rbST), and group control received vitamin E injection. Both treatments started 35 days pre-partum, and were administered every 14 days until parturition. Newborn calves were randomly assigned to the following ages of slaughter: just after birth and without colostrum ingestion; two and seven days of life with colostrum ingestion from their respective mothers. After slaughter, samples from liver and small intestine (jejunum and ileum) were collected for quantification of DNA, RNA, total protein and mRNA of IGF-I and receptor type I. 
A completely randomized design was used with $2 \times 3$ factorial arrangements of treatments, which the factors were the mother's group (control and rbST) and age (just after birth, two and seven days of life). In the liver, RNA and protein concentrations (mg/g tissue) were higher in the second day of age and protein/RNA ratio increased in the seventh day $(P<0.05)$. The jejunum showed interaction among the treatments in the concentrations of DNA and protein, and protein/RNA RNA/DNA ratios $(P<0.05)$. Calves fed colostrum from mothers that received rbST presented, in jejunum, higher DNA concentration in the second day of life, and decrease to intermediate levels between birth and two days, compared to seven days of age. This effect was also observed in protein/RNA ratio. In the control group, it was also verified DNA increase at two days, but there was not difference in the seventh day, and protein/RNA ratio was similar among ages. Protein concentration in jejunum of rbST group increased in the second day and decreased in the seventh, but in the control group, this increase was verified only in the seventh day of age. RNA/DNA ratio decreased in the control group $(P<0.05)$. Expression of IGF-I was higher at birth and seven days old in the liver of the calves from rbST group $(P<0.05)$. The concentrations of receptor type I mRNA decreased with calves' age $(P<0.05)$. At birth, the small intestine of calves showed a condition of cellular response to the presence of IGF-I in colostrum. These results suggest that cells in jejunum of calves from rbST group presented a different phase of maturation. 


\section{INTRODUÇÃO}

O reconhecimento das razões imunológicas para o fornecimento do colostro para bezerros na fase neonatal é um fato estabelecido. Na busca da base biológica para o diferencial de desempenho de recém-nascidos recebendo colostro, verifica-se que o mesmo além de se constituir em fonte de nutrientes e de elementos de proteção, contém várias moléculas biologicamente ativas que são importantes para o crescimento e sanidade animal. Dentre os peptídeos bioativos presentes no colostro e no leite, destacam-se os fatores de crescimento semelhantes à insulina I e II (IGFs), que estimulam mitogênese e diferenciação celular.

A presença de IGF em altas concentrações no colostro sugere um papel importante para o desenvolvimento do recém-nascido. Nas espécies bovinas, IGF-I está presente em concentrações em torno de $200-500 \mathrm{ng} / \mathrm{mL}$ no colostro, diminuindo para $40 \mathrm{ng} / \mathrm{mL}$ do $6^{\circ}$ ao $15^{\circ}$ dia de lactação e para $0,0021 \mathrm{ng} / \mathrm{mL}$ com 150-210 dias (Vacher et al., 1995; MacDonald, 1999).

Os efeitos biológicos dos IGFs presentes no colostro e no leite podem ser observados em inúmeros tecidos. Diversas evidências apontam para esta hipótese, como por exemplo, a presença de receptores de IGF tipo I e tipo II nas células epiteliais da glândula mamária e ao longo de todo o comprimento do intestino do neonato, atuando no crescimento e maturação do trato digestivo. $O$ fornecimento do colostro também está relacionado com maiores níveis circulantes do IGF-I. 
O IGF-I circulante e dos tecidos nos recém-nascidos são derivados principalmente de fontes endógenas, destacando-se o fígado, mas pode ser sintetizado por tecidos extra-hepáticos, apresentando ação autócrina/parácrina. A possibilidade da quantidade de IGF-I, presente no colostro, afetar a expressão gênica deste peptídeo e de seu receptor nos tecidos dos recémnascidos, ainda não está bem compreendida.

O conhecimento da dinâmica intestinal do IGF-I pode contribuir para o entendimento de uma possível constituição do IGF-I das secreções lácteas sobre o crescimento dos enterócitos e de outros tecidos. O presente trabalho teve por objetivo verificar o efeito de diferentes níveis de IGF-I no colostro de vacas que receberam rbST no período pré-parto, no desenvolvimento do trato intestinal e na expressão do gene do IGF-I e de seu receptor no intestino e fígado de bezerros. 


\section{REVISÃO DE LITERATURA}

\subsection{Sistema IGF}

O colostro bovino contém proteínas, aminoácidos essenciais e nãoessenciais, ácidos graxos, lactose, vitaminas e minerais, e também substâncias que exercem funções biológicas específicas, como as imunoglobulinas, peptídeos, fatores de crescimento, citoquinas, esteróides, tiroxina, nucleotídeos, poliaminas e enzimas. O colostro é também caracterizado pelas altas concentrações de IGF-I e II, insulina e prolactina, mas apresenta baixas concentrações do hormônio do crescimento ou somatotropina (ST). A importância do seu fornecimento para o neonato vem sendo relacionada com a transferência de imunidade passiva, fornecimento de nutrientes e maturação dos órgãos do sistema digestivo. Além disso, as mudanças morfológicas, metabólicas, endócrinas, imunológicas e hematológicas, causadas pelo colostro, continuam após o período neonatal (Odle et al., 1996; Blum \& Hammon, 1999).

Os IGFs pertencem à família dos hormônios da insulina e dos fatores de crescimento, representados pela insulina, IGF-I, IGF-II e relaxina (Baumrucker \& Blum, 1993). O IGF-I e o IGF-II são cadeias polipeptídicas simples ( 7,6 kDa) que retêm $70 \%$ da homologia dos aminoácidos entre eles e uma homologia de $50 \%$ com a estrutura da pró-insulina. A seqüência de aminoácidos é altamente conservada entre as espécies, mostrando que o IGF-I apresenta 100\% de 
homologia entre humanos, suínos, ovinos e bovinos, e 96\% para o IGF-II entre humanos e bovinos (Odle et al., 1996).

Como a maioria dos fatores de crescimento, o IGF-I é produzido amplamente pelo organismo. Não é armazenado em grânulos secretores como a maioria dos hormônios clássicos, mas é liberado diretamente assim que é sintetizado. Quantificações da abundância do RNAm indicam que, apesar da síntese do IGF-I ser ubíqua, o fígado é a maior fonte do peptídeo circulante (Murphy et al., 1987). Isso significa que as ações do IGF-I são devidas ao IGF-I produzido localmente e também ao IGF-I hepático presente na circulação, permitindo integração da regulação individual do tecido via sinais sistêmicos coordenados.

Os efeitos biológicos do IGF-I e II são basicamente mediados por receptores específicos, que são identificados por receptores do tipo I e tipo II, respectivamente. O receptor tipo I tem alta afinidade por IGF-I, seguido de IGFII e insulina, enquanto que o receptor tipo II apresenta maior afinidade por IGFII, seguido de IGF-I, mas não se liga à insulina (Odle et al., 1996).

De acordo com Pell (1997), a atividade do IGF-I é o resultado de vários estágios de regulação. Obviamente, sua taxa de biossíntese é importante, mas a modulação de suas atividades, a sua disponibilidade para os receptores nos tecidos por meio das proteínas ligadoras do IGF (IGFBPs), e a sua susceptibilidade à degradação são também importantes para determinar sua atividade.

Pouco IGF-I é encontrado na forma livre "in vivo", sendo, então, ligado a uma das seis proteínas com alta afinidade de ligação ao IGF-I (IGFBPs), as quais modulam a atividade do IGF-I e são sintetizadas em vários tecidos de maneira regular. As seis IGFBPs formam uma família de proteínas que agem sobre o sistema IGF-I de forma funcional, sendo sua concentração variável em função da idade e do estado fisiológico do animal (Hossner et al., 1997). Por não haver um armazenamento do IGF-I, um dos papéis importantes das 
IGFBPs seria o de manter uma reserva do peptídeo. Isso assegura a disponibilidade de um "pool" latente de IGF-I, não excedendo as exigências normais dos tecidos. Esta última função pode ser atribuída particularmente à IGFBP-3, que, depois de associada a uma subunidade ácido lábil (ALS), forma um complexo ternário com peso molecular de $150 \mathrm{kDa}$, prolongando a meiavida do IGF-I (Baxter, 1991).

A ligação do IGF com ALS é restrita ao sangue, sendo a mesma produzida no fígado. Esse complexo é responsável por $90 \%$ do IGF-I circulante. O IGF-I, como um complexo binário com a IGFBP-3, pode atravessar o endotélio capilar. Assim, a formação e dissociação do complexo ternário (IGF-I, IGFBP-3 e ALS) são importantes para a regulação da biodisponibilidade do IGF-I (Dai \& Baxter, 1994; Holman \& Baxter, 1996). Outras IGFBPs (IGFBP-1, $2,-4,-5$ e -6) podem potencializar como também inibir a atividade do IGF-I. As IGFBPs podem não agir meramente como transportadoras dos IGFs, mas conferem aos mesmos funcionalidade e especificidade nos tecidos-alvo, pois influenciam diretamente na ligação e na interação com receptores específicos (Jones \& Clemmons, 1995; McGuire et al., 1995; Clark, 1997).

A ligação do IGF-I e da insulina em seus respectivos receptores resulta em atividades biológicas diferenciadas. O receptor da insulina está, principalmente, envolvido na sinalização metabólica, enquanto que o do IGF-I está envolvido na sinalização mitogênica como um fator de progressão (LeRoith et al., 1994).

A localização dos receptores para insulina e IGF-I pode estar relacionada com diferentes respostas. Os adipócitos apresentam grande quantidade de receptores de insulina e muito pouco do receptor tipo I. A insulina age de maneira aguda e torna a célula com capacidade de resposta para aumentar a transformação de nutriente em gordura e armazenamento no fígado, músculo e ossos. Os receptores de insulina estão presentes em abundância nas células incapazes de se dividir, portanto não são mitogênicos (McCusker, 1998). No 
caso do IGF-I, seus receptores são encontrados em pré-adipócitos, mioblastos, condrócitos, células mesenquimais primárias, fibroblastos, células endoteliais e hepatócitos (Jones \& Clemmons, 1995). Entretanto, em alguns tecidos, o IGF-I também apresenta atividades semelhantes à insulina, como inibição da lipólise, aumento da oxidação de glicose no tecido adiposo e estímulo do transporte de glicose e aminoácidos para os músculos (LeRoith et al., 1994; LeRoith, 1999).

O ciclo celular pode ser dividido em quatro estágios principais: G1 (pré sintético), S (fase de síntese de DNA), G2 (fase pré-mitótica) e M (mitose). Células quiescentes ficam mantidas em uma fase de repouso G0. Na presença de certos fatores competentes como o PDGF (fator de crescimento derivado de plaquetas) e fator de crescimento de fibroblastos (FGF), as células entram no estágio G1. Fatores de progressão como IGF-I e EGF (fator de crescimento epidérmico) são exigidos para a célula passar da fase G1 para a fase S. A maioria das células normais exige mais de um fator de crescimento para a progressão do ciclo celular. Fibroblastos, por exemplo, exigem uma combinação de IGF-I e PDGF ou EGF para o crescimento (Stewart \& Rotwein, 1996).

Dessa maneira, os IGFs são necessários para a proliferação e diferenciação, devido à necessidade da hipertrofia celular antes da mitose e durante o desenvolvimento de funções específicas dos tecidos (síntese de proteína). O IGF-I promove, mas não controla, os processos de proliferação ou diferenciação, como também não controla a morte celular programada (Jones \& Clemmons, 1995; LeRoith, 1999).

O IGF-I originado no fígado é a principal fonte do IGF-I sérico, mas não é necessário para o crescimento pós-natal. Altas concentrações de IGF-I e de seu receptor nos tecidos extra-hepáticos sugerem que sua síntese local possa ter um importante papel no crescimento (Lee et al., 1991). De acordo com Sjögren et al. (1999), o bloqueio da transcrição do gene do IGF-I em camundongos reduziu as concentrações séricas do IGF-I, mas não afetou o crescimento normal e o desenvolvimento dos tecidos extra-hepáticos. Por sua vez, a 
inativação do gene do receptor tipo I resultou em retardo de crescimento em embriões de ratos (Baker et al., 1992).

\subsection{Gene do IGF-I}

O gene do IGF-I de mamíferos tem seis exons, sendo o IGF-I maduro codificado por partes dos exons 3 e 4 . Múltiplas espécies de RNAm são derivadas de "splicings" alternados acima e abaixo dos exons 3 e 4, produzindo potencialmente quatro pré-pro espécies de IGF-I, podendo escolher entre os dois líderes N-terminal e duas seqüências de C-terminal (Lund, 1994).

Em roedores e humanos, na extremidade 5' do gene, os exons 1 e 2 podem se ligar alternativamente ao exon 3 para codificar a seqüência líder do IGF-I com 49 ou 33 resíduos de aminoácidos, respectivamente, sendo que 28 resíduos são codificados pelo exon 3 em ovinos (Pell et al., 1993). O exon 4 codifica 16 resíduos de C-terminal, sendo o restante dos peptídeos nessa extremidade formado por diferentes mecanismos em diferentes espécies. Em humanos e ovinos, o RNAm pode ser derivado de "splicings" alternativos do exon 4 com o exon 5 ou 6 para codificar E-peptídeos num total de 77 (Eb) ou 35 (Ea) resíduos, respectivamente (Rotwein et al., 1986). Em roedores, o peptídeo Ea é formado da mesma maneira que em humanos, mas Eb é derivado do "splicing" dos exons 4, 5 e 6, codificando 41 resíduos. O exon 6, derivado do RNAm, é o mais abundante das espécies do C-terminal e apresenta homologia entre as espécies (Pell, 1997).

A ocorrência de quatro possíveis espécies de RNAm do IGF-I demonstra especificidade fisiológica e tecidual, e pode fornecer um significado na regulação diferencial da síntese e secreção do IGF-I. Em todos os tecidos extrahepáticos, o RNAm do IGF-I é, principalmente, derivado dos exons 1 e 6, conhecidos como transcritos 1-Ea. No fígado, todos os tipos de RNAm são 
expressos, entretanto a classe 1-Ea é normalmente a mais abundante, dependendo do estágio de desenvolvimento e fisiológico (Pell, 1997; Phillips \& Kaytor, 1999).

Kikuchi et al. (1992) observaram que o aumento do RNAm hepático em ratos com 14 dias de vida foi atribuído à transcrição do exon 1 do gene do IGFI. E, após esse período, os aumentos do RNAm derivaram do exon 2 a uma taxa superior aos derivados do exon 1. O significado dessas regulações transcricionais poderia estar relacionado à estabilidade do RNAm, tradução dos diferentes transcritos ou algumas funções da proteína (Pell, 1997).

\subsection{Gene do receptor do IGF-I (receptor tipo I)}

O receptor do IGF-I (tipo I) é uma glicoproteína heterotetramérica de superfície celular, apresentando peso molecular de, aproximadamente, 450 kDa. Consiste de duas subunidades $\alpha(130$ a $140 \mathrm{kDa})$ e duas subunidades $\beta$ (90 a 98 kDa) ligadas por pontes dissulfito (LeRoith et al., 1994).

Como resultado da clivagem proteolítica, as subunidades $\alpha$ e $\beta$ são produzidas e ligadas por pontes dissulfito primárias. A junção pelas pontes dissulfito secundárias das duas cadeias $\alpha-\beta$ resulta na configuração do dímero $\alpha 2 \beta 2$ do receptor maduro. A subunidade $\alpha$ extracelular contém um domínio rico em cisteína, que é codificada pelo exon 3 e está envolvida na ligação do IGF-I com seu receptor. A subunidade transmembrana $\beta$ funde o receptor na membrana plasmática e possui uma porção citoplasmática com atividade tirosina quinase, que é ativada com a ligação do IGF-I na subunidade $\alpha$ (LeRoith et al., 1995).

A ligação do IGF-I ao receptor resulta na autofosforilação deste em resíduos de tirosina intracelulares, aumentando a atividade quinase do domínio em relação aos substratos intracelulares. O receptor se autofosforila e aumenta 
a atividade enzimática, ativando vários outros elementos, incluindo fatores de transcrição nuclear. A ligação de cada uma dessas proteínas tem a capacidade de ativar vários sistemas de sinalização (LeRoith et al., 1995).

A seqüência codificante completa do receptor contém 21 exons. O receptor tipo I é sintetizado como um precursor de cadeia simples de 1367 resíduos de aminoácidos, que contém 30 resíduos do sinal do peptídeo, seguido por seqüências $\alpha$ e $\beta$. Os resíduos Arg-Lys-Arg-Arg no sítio de clivagem formam as subunidades $\alpha$ e $\beta$ de um precursor polipeptídico simples presente no exon 11. O tamanho total do gene do receptor do IGF-I é maior que $100 \mathrm{~kb}$. Entre os 21 exons do gene do receptor do IGF-I, 12 exons são idênticos, em tamanho, ao receptor da insulina, com exceção do primeiro e último exon, entretanto, a homologia entre esses exons é baixa. A região de maior homologia entre os receptores do IGF-I e insulina consiste em cinco exons, 16-20, que codificam o domínio tirosina-quinase na subunidade $\beta$. Quatro desses cinco exons são idênticos em comprimento, consistindo em um limite funcional nessa região, necessário para manter ativa a tirosina-quinase (Abbot et al., 1992).

Diferentes estímulos fisiológicos e patológicos afetam a expressão do gene do receptor tipo I e sua ligação ao IGF-I (Werner et al., 1992). Como exemplo, o "status" nutricional do animal tem influência importante na expressão e atividade de seu receptor (LeRoith et al., 1995). Jejum tem demonstrado aumento na ligação de $\left[{ }^{125}\right.$ I]IGF-I em órgãos como pulmão, testículos, estômago e rins de ratos. Esse aumento foi acompanhado de aumento do RNAm do receptor do IGF-I (Lowe et al., 1987). Se em alguns desses tecidos as concentrações do IGF-I foram diminuídas após a redução de consumo calórico, é possível que os aumentos na expressão do gene do receptor do IGF-I e ligação sejam responsivos às diminuições do IGF-I (Thissen et al., 1994). Similarmente, as concentrações de receptores do IGF-I em 
culturas celulares foram afetadas pela concentração do IGF-I no meio (Le Roith, 1995).

\subsection{Localização dos receptores no trato intestinal}

O RNAm do receptor do IGF-I é um transcrito de baixa abundância, entretanto é distribuído em todos os tipos de tecidos e células (Abbot et al., 1992). As maiores concentrações do RNAm do receptor do IGF-I são encontradas nos estágios embrionários, diminuindo no animal adulto (Bühler et al., 1998; Georgiev et al., 2003).

Devido à complexa morfologia do intestino delgado, torna-se difícil definir a localização celular dos receptores e seus papéis no crescimento, metabolismo e desenvolvimento dos enterócitos (Termanini et al., 1990). Alta afinidade de ligação do IGF-I e IGF-II foi observada nas microvilosidades da mucosa do intestino delgado de camundongos, indicando que ambos receptores do IGF-I e Il estão presentes nos enterócitos (Young et al., 1990).

Os receptores do IGF-I foram encontrados na superfície da serosa e nas regiões da submucosa, tanto na lâmina própria como na muscular da mucosa do intestino delgado, os quais estão correlacionados com a localização da expressão do RNAm do IGF-I (Laburthe et al., 1988; Heinz-Erian et al., 1991; Morgan et al., 1996). Em ratos, a densidade de ambos receptores dos IGFs foi maior nas criptas do que nos vilos, sugerindo maturação celular, ou estando relacionada à função metabólica das células (Young et al., 1990; Morgan et al., 1996).

Hammon \& Blum (2002) demonstraram a presença do receptor tipo I, II e de insulina na mucosa do duodeno, jejuno, íleo e colo de bezerros com oito dias de vida. Entretanto, a distribuição do receptor entre os segmentos foi diferenciada. No intestino delgado, a ligação do IGF-I em seu respectivo 
receptor foi menor no duodeno, que é considerada a região mais ativa para digestão e absorção de nutrientes. A distribuição dos receptores do IGF-I entre a mucosa e a muscular da mucosa também diferiu entre o duodeno e o colo. No duodeno, um maior número de receptores foram associados com a muscular da mucosa do que na mucosa, enquanto que no colo a distribuição foi equivalente (Termanini et al., 1990).

\subsection{IGF-I nas secreções lácteas}

A presença de altas concentrações de fatores de crescimento nas secreções lácteas tem sido relacionada com o crescimento, diferenciação e galactopoese da glândula mamária, como também com o crescimento e desenvolvimento do recém-nascido (Grosvenor et al., 1993). Alguns fatores bioativos são secretados em altas concentrações na glândula mamária durante o período pré-parto, no colostro e nos períodos de involução mamária, podendo alterar funções celulares nos tecidos que estão em contato com os mesmos. As secreções do período pré-parto e de involuções têm potenciais para alterar a função da glândula mamária, estimulando o crescimento e desenvolvimento das células epiteliais mamárias, enquanto que, no colostro, provavelmente, está relacionada com o neonato (Baumrucker \& Blum, 1993, 2002).

Ao comparar as concentrações dos fatores de crescimento no colostro de diferentes espécies, observa-se que o colostro humano e de roedores possuem valores duas a três vezes superiores ao leite, enquanto que o de bovinos e suínos apresentam concentrações 10 a 500 vezes maiores. A concentração média de IGF-I no colostro de bovinos varia de 200 a $500 \mathrm{ng} / \mathrm{mL}$, decrescendo para 1-2 ng/mL no meio da lactação e aumentando para $20-30 \mathrm{ng} / \mathrm{mL}$ ao final da lactação (Simmen et al., 1988; Vega et al., 1991; Donovan et al., 1994; Sejrsen et al., 2001; Pauletti, 2003). Apesar das concentrações absolutas dos 
fatores de crescimento no colostro variarem entre espécies, no geral, o comportamento durante a lactação é similar, apresentando um declínio acentuado durante a transição das secreções pré-parto e colostro para o leite (Baumrucker et al., 1991; Vega et al., 1991).

A somatotropina recombinante bovina exógena (rbST) tem sido muito utilizada em vacas em lactação devida a sua ação galactopoética, sem alteração das exigências líquidas de energia, tornando-se uma alternativa economicamente viável. Entretanto, os detalhes da ação histoquímica da bST na glândula mamária não são totalmente compreendidos (Hossner et al., 1997).

A administração de rbST em vacas secas promove aumento do IGF-I circulante durante o período pré-parto e transferência seletiva deste para as secreções lácteas da glândula mamária (Pauletti, 2003). Hadsell et al. (1993) demonstraram que o aumento de IGF-I circulante pelo tratamento com bST no período seco aumentou também a transferência de IGF-I para o colostro em $40 \%$.

Pelo fato dos IGFs apresentarem natureza estável à acidez e ao calor, é também previsível que sobrevivam aos sucos gástricos e, conseqüentemente, à hidrólise proteolítica, especialmente quando fornecidos a recém-nascidos nas primeiras refeições, ocorrendo o aparecimento desses peptídeos no intestino (Baumrucker \& Blum, 1993; Blum \& Hammon, 1999).

\subsection{IGF-I e o desenvolvimento do trato intestinal}

Apesar dos eventos antes do nascimento prepararem o intestino para a transição da nutrição via placenta para entérica, o crescimento pós-natal e a maturação do intestino são dependentes das características qualitativas e quantitativas da dieta. 
A morfologia e a função do trato intestinal durante o período pós-natal são influenciadas por fatores endógenos e exógenos. Os fatores exógenos que podem ser nutricionais e não-nutricionais, ingeridos com o colostro, apresentam papel importante no desenvolvimento do recém-nascido (Guilloteau et al., 1997; Bühler et al., 1998; Blättler et al., 2001; Blum \& Baumrucker, 2002; Ontsouka et al., 2004). Os IGFs, que interagem com os receptores presentes na maioria dos tecidos, estão sendo principalmente relacionados com a regulação do crescimento e desenvolvimento de todo o organismo, incluindo o desenvolvimento do trato gastrintestinal durante o período pós-natal (Schober et al., 1990; LeRoith et al., 1994; Odle et al., 1996; MacDonald, 1999). Pakkanen \& Aalto (1997) sugeriram que uma dieta rica em IGF-I, como o colostro, provoca o aumento do crescimento e da taxa de renovação celular das células intestinais. Desse modo, contribuirá com um intestino funcionalmente mais eficiente, aumentando a captura dos componentes da dieta e favorecendo processos anabólicos, bem como estimulando o crescimento generalizado.

A baixa atividade de ligação da ST no fígado e as baixas concentrações do IGF-I circulante no neonato (Louveau et al., 2000) sugerem que, apesar do eixo somatotrópico (hipotálamo, hipófise e fígado) ser considerado essencial para o crescimento pós-natal, o seu papel no crescimento neonatal é relativamente limitado (Hammon \& Blum, 1997). Harrell et al. (1999) observaram que leitões recebendo ST exógena apresentaram aumento do IGF-I sérico dependente da idade, ou seja, o tratamento somente resultou em aumentos limitados de IGF-I no início da vida do animal. Breier et al. (1988) verificaram baixos níveis de receptores de ST no fígado de bezerros recémnascidos, indicando que ST não influencia a produção do IGF-I no início da vida.

O desenvolvimento e a proliferação celular intestinal, mediante a ação dos IGFs, podem não ser decorrentes apenas do IGF-I presente no colostro, mas também resultados de estímulos parácrino e/ou autócrino. Análises de tecidos 
fetais e de adultos têm demonstrado que o RNAm do IGF-I é encontrado em todas as regiões do trato gastrintestinal (Bühler et al., 1998; Georgiev et al., 2003). Segundo MacDonald (1999), a rápida taxa de proliferação celular no intestino delgado demanda a participação de múltiplos sistemas regulatórios para assegurar a resposta apropriada para as condições externas e internas. Assim, parece que os IGFs trabalham em conjunto com outros hormônios intestinais.

Uma importante constatação relacionada com os receptores de IGF-I é que são mais abundantes no intestino do recém-nascido do que no do adulto. Isso demonstra que há um sincronismo biológico associado à disponibilidade de resposta da superfície luminal e a presença do IGF-I no colostro (Lee et al., 1993; MacDonald, 1999).

Durante o desenvolvimento pós-natal, a expressão hepática do gene do IGF-I aumenta consideravelmente, coincidindo com os aumentos das concentrações do IGF-I sérico (Cordano et al., 2000). No entanto, a expressão do gene do IGF-I, o número de receptores e a expressão de seu gene diminuem com a idade no intestino de bezerros (Georgieva et al., 2003), ratos (Young et al., 1990) e suínos (Shober et al., 1990; Morgan et al., 1996).

A expressão do RNAm do IGF-I e de seu receptor no intestino e fígado apresenta diferentes respostas em relação ao tipo de dieta líquida fornecida ao recém-nascido. Cordano et al. (2000) estudaram os efeitos do fornecimento de colostro, "pool" de colostro ou sucedâneo para bezerros recém-nascidos até o oitavo dia de vida. Os autores verificaram que o RNAm do IGF-I hepático foi maior no grupo que recebeu colostro comparado ao que recebeu sucedâneo. $O$ mesmo ocorreu com a concentração sérica do IGF-I, indicando que as concentrações séricas estavam positivamente correlacionadas com o RNAm do IGF-I hepático $(r=0,62)$. Nesse caso, o fornecimento de sucedâneo isoenergético e isoprotéico em relação ao colostro resultou em menor expressão hepática do IGF-I. A maior expressão no fígado dos bezerros 
alimentados com colostro foi, provavelmente, influenciada pelo fornecimento de uma maior quantidade de nutrientes para o fígado, conseqüência da maior absorção de nutrientes devido ao crescimento do trato intestinal e da maior habilidade absortiva.

Ao fornecer sucedâneo enriquecido com IGF-I recombinante humano (rhIGF-I), em concentrações fisiológicas, para bezerros durante os primeiros dois dias de vida, Baumrucker et al. (1994) observaram aumento na proliferação celular das criptas, sem alteração da massa ou comprimento da mucosa intestinal, quando comparado aos animais que receberam "pool" de colostro. Já Roffler et al. (2003), não observaram diferenças com relação aos dados histomorfológicos ou taxas de proliferação das células das criptas no intestino delgado e no colo de bezerros que receberam sucedâneo enriquecido com rhIGF-I em concentrações superiores ao colostro (8 a 10 vezes) quando comparados aos que receberam apenas o sucedâneo até os sete dias de vida.

Efeitos positivos do colostro sobre o desenvolvimento do trato intestinal, atribuídos à presença de fatores de crescimento presentes no mesmo, também foram observados por Bühler et al. (1998). O fornecimento de colostro prolongado por três dias para bezerros aumentou a área e a altura das vilosidades do intestino delgado, comparados com os que receberam colostro apenas no primeiro dia de vida, com conseqüente aumento da capacidade absortiva. Por outro lado, Blättler et al. (2001) observaram menores taxas de proliferação celular na mucosa intestinal de bezerros que ingeriram colostro nos três primeiros dias e um "pool" de secreções lácteas por mais quatro dias. Entretanto, não observaram diferenças nas concentrações de DNA, indicando que a densidade celular não foi alterada. Os autores sugeriram que a ingestão de colostro prolongado pode levar ao aumento da sobrevivência e à redução na taxa de "turnover" das células epiteliais do intestino.

A homeostase do tecido intestinal depende da proliferação e da morte celular. A mucosa do intestino é um modelo de rápida renovação celular, onde 
há extrusamento de células do vilo para o lume intestinal, e geralmente, são repostas, em taxas semelhantes, pela proliferação de células nas criptas de Lieberkühn. Mudanças no "status" nutricional, incluindo jejum, excesso de alimentos e o tipo de administração de nutrientes, tais como, nutrição enteral ou parenteral, podem alterar a taxa de renovação dos enterócitos e afetar a massa da mucosa (Winesett et al., 1995). Muitos estudos têm enfocado o controle da proliferação celular, o que inclui os fatores responsáveis pela hiperproliferação. Recentemente, a atenção tem se voltado ao controle da morte celular programada (apoptose), que também é um fator regulador do número de células (Potten et al., 1997). Uma sinalização interna das células pode induzir a morte celular, mas fatores externos podem inibir essa sinalização. O IGF-I tem sido considerado o fator mais importante para a sobrevivência de vários tipos de células (Barres et al., 1992; Harrington et al., 1994). Ainda é desconhecida a ação do IGF-I como inibidor da apoptose, sendo que uma das propostas seria a de ativar a proteína Bcl-2, que é conhecida como uma proteína anti-apoptótica (Potten et al., 1997).

Estudos com nutrição parenteral total (NPT) têm contribuído para o entendimento da ação do IGF-I nas células da mucosa intestinal. O modelo de NPT demonstra que, a indução da hipoplasia na mucosa está associada com as reduções na proliferação dos enterócitos e o aumento da apoptose na cripta e vilo. Devido à falta da nutrição luminal, a NPT induz a hipoplasia da mucosa intestinal, enquanto que a infusão do IGF-I com a NPT, normaliza essas mudanças na cinética dos enterócitos. A habilidade do IGF-I em prevenir ou reverter a atrofia da mucosa, induzida pela NPT, pela estimulação da proliferação dos enterócitos e diminuição da apoptose, atribuem o papel dos fatores de crescimento na regeneração do tecido (Peterson et al., 1997; Dahly et al., 2002).

Dahly et al. (2002) observaram que, a administração do IGF-I em conjunto com a solução da NPT, em ratos, proporcionou aumento da proliferação dos 
enterócitos e diminuição da apoptose na cripta, comparado aos ratos que receberam apenas a NPT. Esta diminuição da apoptose, ou do número médio de células apoptóticas por cripta, se apresentou em valores semelhantes aqueles encontrados em ratos que foram alimentados normalmente. Esse tipo de resposta enfatiza a importância dos promotores de crescimento, que também podem ser estimulados por nutrientes luminais, e são essenciais para manter a integridade intestinal.

O aumento da proliferação das células das criptas e o estímulo do crescimento da mucosa intestinal estão associados com o aumento da expressão do IGF-I (Winesett et al., 1995; MacDonald, 1999). A importância do IGF-I, produzido localmente, é evidenciada pela correlação positiva entre as concentrações dos RNAm do IGF-I e do receptor tipo I com a proliferação celular nas criptas do intestino delgado (Ontsouka et al., 2004). Há também, correlação negativa entre altura de vilo e proliferação celular das criptas, o que sugere aumento de vida útil das células do epitélio intestinal e redução da morte celular, conseqüentemente influenciando o tamanho do vilo (Blättler et al., 2001; Roffler et al., 2003).

Em leitões, nos primeiros dias de vida, o peso do intestino aumenta desproporcionalmente ao peso corpóreo (Shober et al., 1990). Burrin et al. (1996) investigaram o efeito da administração oral de rhIGF-I em doses elevadas (3,5 $\mathrm{mg} / \mathrm{kg}$ peso vivo) sobre o crescimento intestinal de leitões recémnascidos comparada com a quantidade normalmente ingerida proveniente do colostro $(0,1 \mathrm{mg} / \mathrm{kg}$ peso vivo) ou leite $(0,005 \mathrm{mg} / \mathrm{kg}$ peso vivo). Essa dose farmacológica de rhIGF-I aumentou a massa intestinal e foi associada ao aumento de proteína, DNA e altura dos vilos, sem mudanças na profundidade das criptas. Observaram, também, maior ganho de peso após o quarto dia de fornecimento do rhIGF-l, sugerindo que os efeitos sobre o epitélio intestinal podem ter aumentado a capacidade absortiva intestinal e, conseqüentemente, aumentado a disponibilidade de nutrientes para o crescimento somático geral. 
Essa possibilidade também foi considerada no estudo desenvolvido com ratos por Steeb et al. (1994), indicando que o tratamento parenteral prolongado de IGF-I aumentou a absorção intestinal de nitrogênio e o ganho de peso. Já Xu et al. (1994) suplementaram leitões recém-nascidos com doses menores de IGF-I $(0,440 \mu \mathrm{g}$ IGF-l/g/dia) durante 34 horas e não observaram mudanças na massa intestinal, proteína na mucosa intestinal e concentrações de RNA e DNA.

O consumo "ad libitum" de colostro por leitões recém-nascidos durante 36 horas induziu um aumento de $80 \%$ no peso do intestino delgado, causado pela retenção transitória de macromoléculas do colostro e aumento da síntese de proteína (Schober et al., 1990). Os efeitos específicos do colostro na síntese protéica têm sido estudados no trato intestinal e nos tecidos periféricos. A síntese de proteína no trato intestinal foi maior em leitões com sete dias do que com 26 dias de idade (Davis et al., 1996). O efeito estimulatório da ingestão de colostro na síntese de proteína é atribuído, principalmente, ao suprimento de macronutrientes e aos fatores de crescimento presentes no mesmo.

Em contrapartida aos efeitos positivos do IGF-I relatados por diversos autores sobre o crescimento intestinal, alguns estudos não observaram essas mesmas respostas. Por esse motivo, sugere-se que vários outros fatores estejam envolvidos com a ação dos IGFs. Segundo Burrin (1997), a administração oral em doses fisiológicas de IGF-I tem efeitos modestos no crescimento intestinal, sugerindo que o fator predominante que afeta a síntese de proteína no intestino é o consumo de nutrientes. Desse modo, somente uma reduzida estimulação da síntese intestinal protéica pode ser atribuída aos componentes não-nutritivos, incluindo o IGF-I. Para Thissen et al. (1994), o grau de nutrição afeta diretamente a expressão do IGF-I nos tecidos, como também a sua concentração sangüínea. De acordo com Blum \& Hammon (1999), além da quantidade de colostro fornecida, a falta do suprimento de nutrientes nas primeiras horas de vida também afeta o IGF-I sérico, sendo que quanto mais tardiamente for fornecido o colostro, menor será a concentração sérica. 
A expressão do receptor tipo I é dependente do IGF-I sistêmico e daquele em contato com a superfície luminal. Hernandez-Sanchez et al. (1997) observaram que administração sistêmica de IGF-I em ratos diminuiu a expressão do receptor tipo I. Ontsouka et al. (2004) verificaram que o fornecimento de colostro resultou em menor abundância do gene do receptor nas regiões do trato intestinal do que em bezerros alimentados com sucedâneo, com conseqüente diminuição dos receptores no fígado. A ingestão de colostro aumenta as concentrações circulantes de IGF-I, que pode ter efeito negativo na expressão de seu receptor no intestino. Entretanto, Baumrucker et al. (1994) e Georgiev et al. (2003) verificaram que o IGF-I consumido por bezerros na primeira semana de vida resultou em aumento de receptores tipo I, indicando que o IGF-I no lume é capaz de influenciar positivamente a concentração do receptor tipo I.

As concentrações do RNAm do receptor do IGF-I e sua ligação com o IGF-I no fígado, cérebro, estômago, músculo, rins, coração e pulmões diminuem com o desenvolvimento pós-natal (Werner et al., 1992). Em alguns desses tecidos, a diminuição na expressão desse gene é correlacionada com um aumento nos níveis no RNAm do IGF-I e do peptídeo, sugerindo um incremento nos níveis locais e circulantes do IGF-I regulando negativamente a expressão do receptor. No estágio posterior, os baixos níveis do receptor podem ainda influenciar as ações do IGF-I, porque esse ligante media os efeitos do hormônio de crescimento no crescimento longitudinal pela interação com receptores tipo I que estão presentes em grandes quantidades na cartilagem. 


\subsection{Efeitos sistêmicos do IGF-I exógeno}

Há muita discussão sobre o destino do IGF-I presente no colostro ao alcançar o intestino. No início, trabalhos que comparavam a ingestão do colostro com a ingestão de água, sucedâneo ou leite mostraram aumento do IGF-I circulante, levando a conclusão que tal aumento era devido à absorção do IGF-I presente no colostro em maiores quantidades em relação às outras dietas (Baumrucker \& Blum, 1994; Baumrucker et al., 1994; Vacher et al., 1995). No entanto, em trabalhos mais recentes, em que IGF-I marcado ([ $\left.\left.{ }^{125} \mid\right] \mid G F-I\right)$ foi fornecido oralmente, não se detectou absorção desse peptídio (Odle et al., 1996; Burrin, 1997; Wester et al., 1998).

Utilizando quantidades supra-fisiológicas de rhIGF-I para demonstrar a absorção no jejuno, Vacher et al. (1995) verificaram que IGF-I imunoreativo foi absorvido pelo jejuno de bezerros com um dia de vida e tornou-se detectável no sangue obtido da veia mesentérica, mas a absorção ocorreu em curto período. Os autores também observaram que, nos bezerros que ingeriram colostro, a concentração de IGF-I sérica aumentou de forma modesta na primeira semana de vida, no entanto, manteve-se em concentrações superiores àquelas encontradas em bezerros alimentados somente com água, glucose, leite ou sucedâneo no primeiro dia de vida. Todavia, os efeitos do consumo de colostro sobre as concentrações de IGF-I não são invariavelmente positivos. Dentro dessas condições experimentais, o aumento do IGF-I pode ser atribuído ao possível aumento da absorção, mas também ao aumento da produção endógena ou diminuição da taxa metabólica de desaparecimento.

Wester et al. (1998) também verificaram que o fornecimento de colostro a leitões aumentou as concentrações séricas de IGF-I, comparado com os leitões que receberam sucedâneo contendo padrões nutricionais similares aos do colostro. Essa observação sugeriu que há algum outro fator no colostro, além do consumo de macronutrientes, que aumenta o IGF-I circulante. Segundo Odle 
et al. (1996), quando o IGF-I é administrado oralmente no período logo após o nascimento, este pode ser absorvido por bezerros e leitões recém-nascidos, entretanto, a contribuição para o "pool" circulante é quase negligível.

Em estudo detalhado sobre as variações temporais do IGF-I sérico, Kühne et al. (2000) observaram diminuição nas concentrações séricas de IGF-I no período de sete horas após a primeira refeição, e essas concentrações só foram maiores após o terceiro dia de vida. Rauprich et al. (2000) também observaram diminuição da concentração sérica de IGF-I nos primeiros três dias de vida de bezerros, mas não encontraram diferenças no IGF-I sérico de animais que receberam colostro nos três ou sete primeiros dias de vida. 


\section{MATERIAL E MÉTODOS}

\subsection{Animais e tratamentos}

Foram utilizadas 42 vacas da raça Holandesa, multíparas, gestantes e com prenhez de macho confirmada, da Fazenda Agrindus localizada no município de Descalvado, Estado de São Paulo. As vacas foram distribuídas ao acaso em 2 grupos de 21 animais: grupo rbST - recebeu hormônio de crescimento durante o período seco (500 mg rbST - somatotropina recombinante bovina - Boostin) aplicados na fossa ísquio retal, a partir dos 35 dias pré-parto, em intervalos de 14 dias, considerando-se a data prevista para a parição; grupo controle - recebeu injeção de vitamina $\mathrm{E}$ (Monovin-E® - acetato de DL-a-tocoferol $2 \mathrm{mg} / 20 \mathrm{~mL}$ ), também aplicada na mesma região anatômica do grupo 1 e nas mesmas datas de aplicação do hormônio. O fornecimento de vitamina $\mathrm{E}$ para o grupo controle foi em função do hormônio de crescimento adotado ter como excipiente a vitamina $\mathrm{E}$.

Os bezerros recém-nascidos, subdivididos de acordo com o grupo de suas mães, foram distribuídos ao acaso em três idades de abate: após o nascimento e sem a ingestão de colostro; 48 (dois dias) e 168 horas (sete dias) após o nascimento. 


\subsection{Alimentação e manejo dos animais}

Após o nascimento, os bezerros foram separados das mães, pesados, identificados e alojados em baias. Uma quantidade de colostro referente a $5 \%$ do peso vivo dos bezerros, proveniente das respectivas mães, foi fornecida nas primeiras quatro horas de vida. Animais que apresentaram dificuldade em mamar, receberam o colostro através de sonda esofagiana. Para essa operação, as vacas foram monitoradas 24 horas para assegurar que o bezerro fosse separado da mãe logo após o nascimento, e que recebesse a quantidade de colostro determinada. Após a ingestão do colostro, os animais passaram a receber as próximas secreções lácteas da própria mãe, na quantidade de $4 \mathrm{~L}$ divididos em duas refeições diárias até a idade de abate.

\subsection{Coleta de amostras}

Foram coletadas amostras de sangue dos bezerros antes da ingestão do colostro e no dia do abate, retiradas da veia jugular. Após a centrifugação, o soro resultante de cada amostra foi armazenado a $-20^{\circ} \mathrm{C}$.

Nas datas de abate, os animais foram pesados, anestesiados e exsangüinados, sendo o fígado e segmentos do intestino delgado (jejuno e íleo) isolados e coletadas amostras. Os tecidos foram lavados com solução salina $(0,9 \% \mathrm{NaCl})$ e rapidamente congelados em nitrogênio líquido para análises posteriores. 


\subsection{Análises}

\subsubsection{Quantificação do IGF-I}

As concentrações de IGF-I no soro dos bezerros foram quantificadas por ensaio imunoradiométrico pós-extração, utilizando-se o kit DSL-5600 (Diagnostic Systems Laboratories, Inc.) e quantificados em um contador gama (Automatic Gamma Counter 1470, Wizard TM Wallac). A quantificação foi realizada no Laboratório Fleury, SP. As concentrações de IGF-I foram apresentadas em $\mathrm{ng} / \mathrm{mL}$.

\subsubsection{Extração de RNA total}

Para a extração do RNA total, 50 a $60 \mathrm{mg}$ dos tecidos (fígado, jejuno e íleo) foram dissolvidos em $750 \mu \mathrm{L}$ de Trizol (Invitrogen ${ }^{\mathrm{TM}}$ ) e $250 \mu \mathrm{L}$ de $\mathrm{H}_{2} \mathrm{O}_{\text {DEPC }}$ (água tratada com $0,01 \%$ de dietilpirocarbonato), e posteriormente, incubados por 5 min a temperatura de $15-30^{\circ} \mathrm{C}$, para que ocorresse a completa dissociação de complexos nucleoprotéicos. Posteriormente, foram adicionados $200 \mu \mathrm{L}$ de clorofórmio às amostras, agitadas vigorosamente por 15 segundos e incubadas por $10 \mathrm{~min}$ a $15-30^{\circ} \mathrm{C}$. As amostras foram centrifugadas a $12000 \mathrm{~g}$ por 15 min em centrífuga refrigerada a $4^{\circ} \mathrm{C}$. Após esta centrifugação, houve separação de DNA e RNA, e o RNA que permaneceu na fase aquosa foi transferido para outro microtubo, precipitado com isopropanol e centrifugado nas mesmas condições anteriores. O sobrenadante foi descartado e o pelete foi lavado em etanol $75 \%$ e centrifugado. Após a lavagem, o pelete foi seco ao ar por 10 min, e então, ressuspendido com $40 \mu \mathrm{L}$ de $\mathrm{H}_{2} \mathrm{O}_{\text {DEPC. }}$. A quantificação do RNA foi feita em espectrofotômetro UV-1601 PC SHIMADZU (260-280nm), e 1 
$\mu \mathrm{L}$ do RNA foi submetido à eletroforese em gel de agarose $1,5 \%$ para observar a integridade do RNA total.

\subsubsection{Reação de Transcrição Reversa}

Uma alíquota de $1 \mu \mathrm{g}$ do RNA total foi utilizada na síntese do DNA complementar (DNAc), utilizando-se 50U da enzima Transcriptase Reversa "Superscript ${ }^{\mathrm{TM}}$ First-Strand Synthesis System for RT-PCR" (Invitrogen ${ }^{\mathrm{TM}}$ ). Na reação, utilizou-se uma alíquota de $1 \mu \mathrm{g}$ do RNA total, $1 \mu \mathrm{L}$ de $10 \mathrm{mM}$ dNTP mix, $2 \mu \mathrm{L}$ de "primers random hexamers" (50 ng/ $\mu \mathrm{L}$ ) e completou-se até $10 \mu \mathrm{L}$ com $\mathrm{H}_{2} \mathrm{O}_{\text {DEPC. }}$. As amostras foram incubadas a $65^{\circ} \mathrm{C}$ por $5 \mathrm{~min}$, e então, mantidas no gelo por pelo menos $1 \mathrm{~min}$. Foram adicionados $2 \mu \mathrm{L}$ de 10xRT buffer, $4 \mu \mathrm{L}$ de $25 \mathrm{nM} \mathrm{MgCl} 2,2 \mu \mathrm{L}$ de 0,1 M DTT e $1 \mu \mathrm{L}$ de RNaseOUT Recombinant Ribonuclease Inhibitor, permanecendo por 2 min a $25^{\circ} \mathrm{C}$. Posteriormente, foi acrescentado $1 \mu \mathrm{L}(50 \mathrm{U})$ de "SuperScript ${ }^{\mathrm{TM}} \mathrm{RT}$ ", incubado a $25^{\circ} \mathrm{C}$ por $10 \mathrm{~min}, 42^{\circ} \mathrm{C}$ por $50 \mathrm{~min}, 70^{\circ}$ por $15 \mathrm{~min}$ e resfriado em gelo. Para a remoção da fita de RNA da molécula híbrida DNAc:RNA, adicionou-se $1 \mu \mathrm{L}$ de RNAse $\mathrm{H}$ e foi colocado em banho a $37^{\circ} \mathrm{C}$ por $20 \mathrm{~min}$.

\subsubsection{Obtenção dos "primers"}

A seqüência dos "primers" senso (direto) e anti-senso (reverso) específicos para amplificação da seqüência dos genes que codificam o IGF-I e seu receptor (receptor tipo I) foram obtidos a partir do trabalho de Pfaffl et al. (2002). Nesse trabalho, os autores utilizaram a técnica de PCR em tempo real utilizando o equipamento "LightCycler" (Roche), sendo o mesmo utilizado no presente estudo. O tamanho do fragmento do gene do IGF-I compreendeu 240 pb (exons 3-4), enquanto que o do receptor tipo I foi de 314 pb (exons 11-12). 
As seqüências dos "primers" utilizados e os fragmentos amplificados estão apresentados a seguir:

IGF-I

PRIMER SENSO

5' TCGCATCTCTTCTATCTGGCCCTGT 3'

PRIMER ANTI-SENSO

5' GCAGTACATCTCCAGCCTCCTCAGA 3'

Seqüência IGF-I

"primer" senso

TCGCATCTCTTCTATCTGGCCCTGTGCTTGCTCGCCTTCACCAGCTCTGCCA CGGCGGGACCCGAGACCCTCTGCGGGGCTGAGTTGGTGGATGCTCTCCAG TTCGTGTGCGGAGACAGGGGCTTTTATTTCAACAAGCCCACGGGGTATGGC TCGAGCAGTCGGAGGGCGCCCCAGACAGGAATCGTGGATGAGTGCTGCTT CCGGAGCTGTGATCTGAGGAGGCTGGAGATGTACTGC

"primer" anti-senso

\section{Receptor tipo I}

PRIMER SENSO

5' TTAAAATGGCCAGAACCTGAG 3'

PRIMER ANTI-SENSO

5' ATTATAACCAAGCCTCCCAC 3'

Seqüência do receptor tipo I 
"primer" senso

TTAAAATGGCCAGAACCTGAGAATCCCAATGGATTGATCCTCATGTATGAA

ATAAAATATGGATCCCAAGTCGAGGATCAGCGGGAATGTGTGTCCAGACAG GAGTACAGGAAGTATGGAGGAGCCAAGCTAAACCGGCTCAACCCAGGGAA CTACACAGCCCGGATCCAGGCCACCTCTCTCTCTGGGAATGGGTCGTGGA CGGATCCCGTGTTCTTCTACGTTCAGGCCAAGACGACATATGAGAACTTCA TCCACCTGATGATCGCTCTGCCCATTGCGGTTCTGTTGATAGTGGGAGGCT TGGTTATAAT

"primer" anti-senso

\subsubsection{Otimização de condições de PCR}

A otimização dos "primers" foi feita através de uma reação de PCR, no aparelho RoboCycler ${ }^{\circledR}$ Gradient 96 (Stratagene), utilizando-se DNAc de amostras do fígado, jejuno e íleo. Os produtos amplificados foram submetidos à eletroforese em gel de agarose $1,5 \%$ e corados com brometo de etídio. 0 tamanho das bandas foi comparado a um marcador de peso molecular conhecido, o $\Phi$ X174 RF DNA/Haelll (Invitrogen ${ }^{\mathrm{TM}}$ ). Para confirmação da seqüência de IGF-I, os produtos amplificados foram seqüenciados (ABI 3100 HITACHI) no Laboratório de Biotecnologia Animal, ESALQ/USP.

Os programas utilizados para a amplificação dos genes do IGF-I e do receptor tipo I estão apresentados na Tabela 1. 
Tabela 1. Condições de amplificação dos genes do IGF-I e receptor tipo I no termociclador RoboCycler®

\begin{tabular}{lccc}
\hline & \multicolumn{2}{c}{ Temperatura $\left({ }^{\circ} \mathrm{C}\right)$} & $\begin{array}{c}\text { Tempo } \\
\text { min. }\end{array}$ \\
\cline { 2 - 3 } & IGF-I & Receptor tipo I & 10 \\
\hline $1^{\circ}$ Ciclo & 95 & 95 & 1 \\
& 66 & 60 & 1 \\
$2^{\circ}-34^{\circ}$ Ciclo & 74 & 74 & 1 \\
& 95 & 95 & 1 \\
$35^{\circ}$ Ciclo & 66 & 60 & 1 \\
& 74 & 74 & 1 \\
& 95 & 95 & 1 \\
& 66 & 60 & 10 \\
\hline
\end{tabular}

\subsubsection{Clonagem das seqüências}

Após a confirmação das seqüências, os produtos de PCR foram clonados, em bactérias eletrocompetentes $E$. coli DH10B utilizando-se o kit TOPO TA Cloning Kit ${ }^{(I n v i t r o g e n}{ }^{\mathrm{TM}}$ ).

Para a reação de ligação foram adicionadas $0,8 \mu \mathrm{L}$ do produto de PCR fresco, $1 \mu \mathrm{L}$ da solução salina (1,2M NaCl, $\left.0,06 \mathrm{M} \mathrm{MgCl}_{2}\right), 1 \mu \mathrm{L}$ do vetor $p C R \circledast 4-$ TOPO $®$ e $2,2 \mu \mathrm{L}$ de água estéril. A reação foi gentilmente misturada e incubada por 5 minutos em temperatura ambiente, seguindo-se a incubação no gelo. $\mathrm{Na}$ reação de transformação, realizada por eletroporação, $2 \mu \mathrm{L}$ da reação de 
ligação foram adicionadas em cubetas geladas contendo $50 \mu \mathrm{L}$ de $E$. coli DH10B. Após a eletroporação foram adicionadas $250 \mu \mathrm{L}$ de meio SOC (2\% triptona, $0,5 \%$ extrato de levedura, $10 \mathrm{mM} \mathrm{NaCl}, 2,5 \mathrm{mM} \mathrm{KCl}, 10 \mathrm{mM} \mathrm{MgCl}_{2}, 10$ $\mathrm{mM} \mathrm{MgSO}_{4}$ e $20 \mathrm{mM}$ glucose), transferidas para um microtubo e incubadas por 1 hora a $37^{\circ} \mathrm{C}, 200 \mathrm{rpm}$.

Foi realizado o plaqueamento com $50 \mu \mathrm{L}$ e $10 \mu \mathrm{L}$ da reação em meio LB ágar ( $1 \%$ triptona, $0,5 \%$ extrato de levedo, $05 \% \mathrm{NaCl}$ e $1,5 \%$ ágar) com 50 $\mu \mathrm{g} / \mathrm{mL}$ de ampicilina, e incubadas "overnight" a $37^{\circ} \mathrm{C}$. No dia seguinte, colônias individuais foram coletadas e colocadas em meio LB líquido, e mantidas a $37^{\circ} \mathrm{C}$, à velocidade de $200 \mathrm{rpm}$ durante toda a noite. Seguiu-se à extração de plasmídios.

\subsubsection{Extração de plasmídios}

Foram coletados $1,5 \mathrm{~mL}$ da cultura, colocados em microtubos $\mathrm{e}$ centrifugados por 30 segundos. O sobrenadante foi descartado e suspendeu-se o pelete formado com $200 \mu \mathrm{L}$ de GET $(25 \mathrm{mM}$ de Tris $\mathrm{HCL}$ ph 8,0, $10 \mathrm{mM}$ de EDTA ph 8,0). Foram adicionados $300 \mu \mathrm{L}$ de uma solução contendo $1 \%$ de SDS e $0,2 \%$ de $\mathrm{NaOH}$. Os microtubos foram incubados em banho de gelo por 5 minutos, e adicionados $300 \mu \mathrm{L}$ de acetato de potássio $3 \mathrm{M}$, seguindo-se novamente a incubação no gelo por 5 minutos. Posteriormente, os tubos foram centrifugados a $13000 \mathrm{rpm}$, por 10 minutos, a temperatura ambiente. O sobrenadante foi transferido para um novo microtubo e adicionados $10 \mathrm{mg} / \mathrm{mL}$ de RNAse A. Em seguida, foi feita a incubação a $37^{\circ} \mathrm{C}$ por 10 minutos, seguida da adição de $400 \mu \mathrm{L}$ de clorofórmio e centrifugação a 13000 rpm por 1 minuto.

A fase superior foi transferida para um novo microtubo e adicionados o mesmo volume de isopropanol absoluto, centrifugado a $13000 \mathrm{rpm}$ por 10 minutos, a temperatura ambiente. Descartou-se o sobrenadante e adicionou-se 
$500 \mu \mathrm{L}$ de etanol $70 \%$, e centrifugou-se por 5 minutos a $13000 \mathrm{rpm}$. O pelete resultante foi ressuspendido em $32 \mu \mathrm{L}$ de $\mathrm{H}_{2} \mathrm{O}$. Foram adicionados $8 \mu \mathrm{L}$ de $\mathrm{NaCl} 4 \mathrm{M}$ e $40 \mu \mathrm{L}$ de polietileno glicol (PEG) $13 \%$ e mantidos em banho de gelo por 20 minutos. Seguiu-se centrifugação a $4^{\circ} \mathrm{C}, 13000 \mathrm{rpm}$, por 15 minutos. $\mathrm{O}$ sobrenadante foi removido e, ao pelete resultante, foram adicionadas $500 \mu \mathrm{L}$ de etanol $70 \%$. Prosseguiu-se com centrifugação a temperatura ambiente, 13000 rpm, por 5 minutos. O pelete foi ressuspendido em $20 \mu \mathrm{L}$ de $\mathrm{H}_{2} \mathrm{O}$.

Para a confirmação do material clonado, após a extração dos plasmídios, foi feita uma reação de PCR utilizando "primers" M13 que anelam no vetor permitindo a amplificação do fragmento clonado, e posteriormente, visualização do tamanho das bandas clonadas através de gel de agarose 1,5\%. Para comparação do tamanho dos fragmentos foi utilizado o marcador de peso molecular \$X174 RF DNA/Haelll. Depois de escolhidos os clones, estes foram submetidos ao seqüenciamento. Desse modo, encontrou-se clones com os fragmentos inseridos apresentando $100 \%$ de homologia com as seqüências de interesse.

\subsubsection{Gene da $\beta$-actina}

O gene da $\beta$-actina foi utilizado como gene constitutivo e um clone contendo um inserto de $229 \mathrm{pb}$ (exons 2-3) da $\beta$-actina de bovinos, clonada em plasmídio pGEM® $4 Z_{(+)}$, gentilmente cedido pelo Prof. Dr. Dante Pazzanese Duarte Lanna, Laboratório de Nutrição e Crescimento Animal, ESALQ/USP.

O fragmento do gene da $\beta$-actina, inserido em bactérias Escherichia coli da linhagem JM109, estava estocado em meio LB com 50\% de glicerol. Foram plaqueadas $100 \mu \mathrm{L}$ da cultura em meio LB ágar contendo $50 \mu \mathrm{g} / \mathrm{mL}$ de ampicilina, 0,1 mM/mL de IPTG e $40 \mu \mathrm{g} / \mathrm{mL}$ de X-gal, deixadas durante a noite a $37^{\circ} \mathrm{C}$. 
Posteriormente, colônias isoladas foram incubadas em $5 \mathrm{~mL}$ de meio LB, contendo $50 \mu \mathrm{g} / \mathrm{mL}$ de ampicilina, mantidas a $37^{\circ} \mathrm{C}, 200 \mathrm{rpm}$, "overnight". A seguir, foi feita a extração de plasmídios, como detalhado anteriormente.

As seqüências de "primers" da $\beta$-actina utilizadas foram as seguintes:

PRIMER SENSO

5' CTAGGCACCAGGGCGTCATG 3'

PRIMER ANTI-SENSO

5'CTTAGGGTTCAGGGGGGCCT 3'

Seqüência da $\beta$-actina

"primer" senso

CTAGGCACCAGGGCGTCATGGTGGGCATGGGCCAGAAGGACTCGTACGT GGGGGATGAGGCTCAGAGCAAGAGAGGCATCCTGACCCTCAAGTACCCCA TTGAGCACGGCATCGTCACCAACTGGGACGACATGGAGAAGATCTGGCAC CACACCTTCTACAACGAGCTCCGTGTGGCCCCTGAGGAGCACCCCGTGCT GCTGACCGAGGCCCCCCTGAACCCTAAGGC

"primer" anti-senso 


\subsubsection{Cálculos das diluições dos clones para a curva padrão do IGF-I e receptor tipo I}

A utilização de uma curva padrão para o gene de interesse permite medir quantidades absolutas de expressão do RNAm em pequena quantidade de amostra. Para se produzir as curvas padrões dos genes do IGF-I, receptor tipo I e $\beta$-actina, utilizou-se o material clonado, que teve os plasmídios extraídos e medida a quantidade de DNA em espectrofotômetro (UV-1601 PC SHIMADZU), obtendo-se a concentração em ng/ $\mu \mathrm{L}$.

Foram calculados os pesos moleculares de cada clone, em Daltons, para se determinar a concentração de cada DNA equivalente ao número de moléculas/ $\mu \mathrm{L}$. A fórmula utilizada foi a seguinte:

$\left[\left(\right.\right.$ massa de DNA $(\mathrm{g}) \times\left(6,02 \times 10^{\underline{23}} \underline{\text { moléculas } / \text { mole })]}=\right.$ moléculas

$\mathrm{g}$ de peso molecular ( $\mathrm{g} / \mathrm{mole}$ ou Daltons)

Assim, através de diluições seriadas, foram construídas curvas padrões com sete pontos para os genes do IGF-I, receptor tipo I e $\beta$-actina.

\subsubsection{PCR em tempo real}

Para a quantificação da expressão gênica de IGF-I e seu receptor nos segmentos do intestino delgado e fígado, a técnica de PCR denominada PCR em tempo real foi desenvolvida no equipamento "LightCycler" PCR (Laboratório de Biotecnologia Animal, ESALQ/USP) de acordo com Pfaffl (2000), através da metodologia do SYBR Green I. Esta técnica baseia-se na utilização de um 
corante fluorescente (SYBR Green I) que se liga ao fragmento durante a fase de anelamento, aumentando o sinal fluorescente. Através do "LigthCycler Software" a fluorescência emitida pelo corante é determinada durante a fase "log" do PCR sendo possível determinar a quantidade inicial do material estudado (Gibson et al., 1996).

As condições de PCR utilizadas para os genes estudados estão apresentados na tabela 2 .

Tabela 2. Condições de PCR em tempo real dos genes do IGF-I, receptor tipo I e $\beta$-actina utilizando-se o "LightCycler"

\begin{tabular}{lcccc}
\hline Segmentos & Duração (s) & \multicolumn{3}{c}{ Temperatura $\left({ }^{\circ} \mathrm{C}\right)$} \\
\hline Desnaturação - 1 ciclo & 30 & & 95 & \\
Amplificação - 45 ciclos & & IGF-I & Receptor & $\beta$-actina \\
1-Desnaturação & 5 & 95 & 95 & 95 \\
2-Anelamento & 10 & 62 & 63 & 55 \\
3-Alongamento & 15 & 72 & 72 & 72 \\
4-Aquisição de fluorescência & 3 & 86 & 87 & 87 \\
Análise da curva de "melting" - 1 ciclo & & & & \\
Segmento 1 & 10 & 95 & 95 & 95 \\
Segmento 2 & 10 & 60 & 73 & 65 \\
\hline
\end{tabular}




\subsubsection{Cálculos da quantificação dos genes do IGF-I e receptor tipo I}

Os resultados fornecidos pelo "LightCycler Software" foram apresentados como número de moléculas, de acordo com a curva padrão que foi utilizada. Os valores foram normalizados baseando-se na média dos valores encontrados de $\beta$-actina nos tecidos.

Os resultados foram expressos como número de moléculas por $\mathrm{mg}$ de tecido. Essa concentração foi calculada como se segue:

Peso molecular $(\mathrm{g} / \mathrm{mol})=($ número pares base $) \times(660$ Da por pares de base $)$

A quantidade presente em $1 \mathrm{mg}$ de tecido foi calculada de acordo com a equação:

Quantidade $=\underline{\text { (número de moléculas por } \mathrm{mg} \text { tecido } \mathrm{X} \text { peso molecular) }}$

$6,023 \times 10^{23}$

\subsubsection{Extração e quantificação do DNA total}

A determinação de DNA total no fígado, jejuno e íleo foram feitos de acordo com o método de Labarca \& Paigen (1980).

Para extração do DNA total, $19 \mathrm{~mL}$ de $\mathrm{H}_{2} \mathrm{O}$ foram adicionados a $1 \mathrm{~g}$ do tecido e homogeneizado três vezes, a $11000 \mathrm{rpm}$, por 1 min cada, utilizando-se Politron PT2100 (Kinemática AG). Transferiu-se $1 \mathrm{~mL}$ do homogenato para microtubo e acrescentou-se $0,5 \mathrm{~mL}$ de ácido perclórico (PCA) $0,6 \mathrm{M}$, deixado "overnight" a $4^{\circ} \mathrm{C}$. No dia seguinte, a solução foi homogeneizada com "vortex" e 
descansou por 10 min a $4^{\circ} \mathrm{C}$. A seguir, as amostras foram centrifugadas por 15 minutos, $6000 \mathrm{rpm}$ e a $4^{\circ} \mathrm{C}$. Após descartar o sobrenadante, o "pelete" foi lavado 2 vezes com $0,4 \mathrm{~mL}$ de PCA 0,2N. A cada lavagem, centrifugou-se nas mesmas condições citadas anteriormente. Posteriormente, foi adicionado 0,8 $\mathrm{mL}$ de hidróxido de potássio $0,3 \mathrm{~N}$, misturados imediatamente e incubados a $37^{\circ} \mathrm{C}, 150 \mathrm{rpm}$, por 1 hora. Prosseguiu-se a extração com a incubação das amostras por 5 minutos no gelo e adição de $0,4 \mathrm{~mL}$ de PCA 1,2N gelado, e descanso de 10 minutos. Seguiu-se com a centrifugação a $6000 \mathrm{rpm}, 15$ minutos a $4^{\circ} \mathrm{C}$, o sobrenadante foi transferido para um novo tubo e utilizado posteriormente para a quantificação do RNA total. O pelete resultante foi enxaguado duas vezes com $1 \mathrm{~mL}$ de PCA $0,2 \mathrm{~N}$ gelado. A cada enxágüe, 0 sobrenadante foi adicionado ao anterior (RNA), e o pelete resultante foi congelado a $-20^{\circ} \mathrm{C}$.

Para quantificar o DNA, este foi descongelado e dissolvido em $1 \mathrm{~mL}$ de hidróxido de potássio $0,1 \mathrm{~N}$ e deixado "overnight". No dia seguinte, $1000 \mu \mathrm{L}$ de solução contendo $1 \mu \mathrm{g} / \mathrm{mL}$ de corante Hoechst (bis-bensimida H33258, Calbiochem), $1 \mathrm{mM}$ EDTA, $2 \mathrm{M} \mathrm{NaCl}$ e $10 \mathrm{mM}$ Tris, foram adicionados a $40 \mu \mathrm{L}$ da amostra de DNA e $60 \mu \mathrm{L}$ de $\mathrm{H}_{2} \mathrm{O}$. Essa solução foi quantificada no fluorímetro HOEFER DyNA Quanti 200 (Laboratório de Biotecnologia Animal). DNA de timo de bezerro (Amersham Biosciences) foi utilizado para se montar uma curva padrão. Os resultados foram apresentados como mg de DNA/g de tecido.

\subsubsection{Quantificação do RNA total}

O RNA extraído do protocolo acima, foi descongelado e adicionados $3 \mathrm{~mL}$ de PCA $0,2 \mathrm{~N}$, e lidos em espectrofotômetro (UV-1601 PC SHIMADZU), a $260 \mathrm{~nm}$ e $280 \mathrm{~nm}$ (correção de proteína). Os resultados foram apresentados como mg de RNA/g de tecido. 


\subsubsection{Quantificação da proteína total}

A quantificação da proteína total foi determinada pelo método de Lowry et al. (1951). Misturou-se $1 \mathrm{~mL}$ do homogenato obtido anteriormente com $1 \mathrm{~mL}$ $\mathrm{NaOH} 1 \mathrm{M}$ triton $0,2 \%$, e deixado "overnight". No dia seguinte, na relação de 1 parte de solução $\mathrm{A}\left(2 \% \mathrm{Na}_{2} \mathrm{CO}_{3}\right.$ e $\left.01, \mathrm{~N} \mathrm{NaOH}\right)$ para 50 partes de solução $\mathrm{B}$ ( $1 \%$ $\mathrm{CuSO}_{4}$ e $1 \mathrm{~N}$ citrato de sódio), acrescentou-se $400 \mu \mathrm{L}$ desta solução a $80 \mu \mathrm{L}$ da solução protéica, e aguardou-se 1 minuto. Em seguida, adicionou-se $40 \mu \mathrm{L}$ da solução de Folin ( $20 \mu \mathrm{L}$ reagente Folin, Merck, e $20 \mu \mathrm{L}$ de $\mathrm{H}_{2} \mathrm{O}_{\mathrm{MQ}}$ ). Após 20 minutos de reação procedeu-se a leitura da absorbância em espectrofotômetro UV-1601 PC SHIMADZU, com comprimento de onda ajustado em 600nm. Para cada bateria de amostras, estabeleceu-se uma curva padrão que relacionava concentrações conhecidas de proteína (albumina bovina - Sigma Chemical Company) a valores de absorbância obtidos das amostras. Os resultados foram apresentados como $\mathrm{mg}$ de proteína/g de tecido.

\subsection{Análise estatística}

Para todas as variáveis estudadas, foi utilizado delineamento inteiramente casualizado e os tratamentos foram dispostos numa estrutura fatorial $2 \times 3$, correspondendo ao grupo da mãe (rbST ou controle) e idades (ao nascimento, dois ou sete dias de idade).

O modelo utilizado para análise foi: 


$$
Y_{I J K}=\mu+T_{i}+A_{j}+I_{i j}+e_{i j k}
$$

$\mathrm{Y}_{\mathrm{IJK}}=$ observação do indivíduo $\mathrm{k}$, pertencente ao grupo i e a idade j;

$\mu=$ média geral;

$\mathrm{T}_{\mathrm{i}}=$ efeito do i-ésimo grupo;

$A_{j}=$ efeito do j-ésimo idade;

$\mathrm{I}_{\mathrm{ij}}=$ efeito da interação do i-ésimo grupo com o j-ésimo idade;

$\mathrm{e}_{\mathrm{ijk}}=$ erro aleatório associado a cada observação ijk, suposto normalmente distribuído e independente, com média zero e variância $\sigma^{2}$.

Todos os dados foram submetidos à análise de variância, através do procedimento "General Linear Model" (PROC GLM) do programa estatístico SAS (1991). Para a avaliação de diferenças entre médias de idade, foram efetuados contrastes entre pares de médias utilizando-se o método de Tukey. Nos casos em que houve interação, os efeitos do tratamento que as vacas receberam foram analisados dentro de cada idade, como também as idades foram analisadas dentro de cada tratamento. Para todas as análises utilizou-se o nível de significância de 5\%.

Foi utilizada a transformação logarítmica das variáveis de expressão do gene do IGF-I e receptor tipo I, pois não possuem distribuição normal.

Análises de correlação, Pearson, foram realizadas para verificar associações de interesse entre as variáveis de expressão e séricas. 


\section{RESULTADOS E DISCUSSÕES}

\subsection{Concentrações de DNA, RNA e proteína no fígado e tecidos do trato intestinal}

\subsubsection{Ingestão de colostro}

Os bezerros utilizados neste trabalho ingeriram $5 \%$ do peso vivo de colostro proveniente das próprias mães. O colostro de vacas que receberam rbST durante o período seco apresentou, em média, 874,53 $\pm 335,02 \mathrm{ng} / \mathrm{mL}$ de IGF-I, enquanto que colostro das vacas do grupo controle apresentou concentração de IGF-I de 674,15 $\pm 259,53 \mathrm{ng} / \mathrm{mL}$ ( $P<0,05)$. Portanto, os bezerros das vacas do grupo rbST ingeriram uma quantidade de IGF-I cerca de $30 \%$ superior.

A quantificação da concentração de DNA nos tecidos é uma medida que avalia a densidade celular, sendo um indicativo de proliferação celular. Para esta variável, não foi encontrado efeito do fornecimento do colostro proveniente de vacas que receberam rbST durante o período pré-parto (grupo rbST) ou grupo controle e nem da idade, no fígado e íleo dos bezerros (Tabela 3). No íleo foram observadas diferenças entre as idades, sendo que os animais aos sete dias de vida apresentaram maior concentração de DNA do que ao nascimento $(P<0,05)$. 
Tabela 3. Concentrações de DNA, RNA e proteína no fígado, jejuno e íleo, nas diferentes idades de bezerros que receberam colostro de vacas controle ou submetidas à administração de rbST durante o período pré-parto

\begin{tabular}{|c|c|c|c|c|c|c|c|c|c|}
\hline \multirow{2}{*}{ Tecidos } & \multicolumn{2}{|c|}{ Grupo $^{1}$} & \multicolumn{3}{|c|}{ Idade (dias) ${ }^{2}$} & \multirow{2}{*}{$\mathrm{EPM}^{3}$} & \multicolumn{3}{|c|}{ Probabilidade $^{4}$} \\
\hline & Controle & rbST & 0 & 2 & 7 & & Grupo & Idade & Gr. vs. Id. \\
\hline \multicolumn{10}{|c|}{ DNA, mg/g tecido } \\
\hline Fígado & 5,7 & 5,7 & 5,3 & 5,9 & 5,9 & 0,26 & NS & NS & NS \\
\hline Íleo & 4,8 & 5,1 & $4,2^{b}$ & $5,0^{a b}$ & $5,7^{\mathrm{a}}$ & 0,24 & NS & 0,03 & NS \\
\hline \multicolumn{10}{|c|}{ RNA, mg/g tecido } \\
\hline Fígado & 20,0 & 19,8 & $17,1^{\mathrm{b}}$ & $24,2^{a}$ & $18,4^{b}$ & 0,65 & NS & $<0,01$ & NS \\
\hline Jejuno & 13,7 & 13,1 & $11,5^{\mathrm{b}}$ & $14,8^{a}$ & $13,9^{a}$ & 0,33 & NS & $<0,01$ & NS \\
\hline Íleo & 15,4 & 15,7 & $14,9^{b}$ & $14,7^{\mathrm{b}}$ & $17,1^{\mathrm{a}}$ & 0,35 & NS & $<0,01$ & NS \\
\hline \multicolumn{10}{|c|}{ PROTEÍNA, mg/g tecido } \\
\hline Fígado & 135,5 & 130,0 & $117,3^{b}$ & $149,3^{a}$ & $131,7^{\mathrm{ab}}$ & 4,8 & NS & 0,02 & NS \\
\hline Íleo & 95,7 & 96,4 & 86,6 & 101,3 & 100,2 & 3,4 & NS & NS & NS \\
\hline
\end{tabular}


No jejuno observou-se efeito de interação entre grupos controle ou rbST com as idades $(P<0,05)$. Para compreender essa interação, o grupo das vacas foi fixado, e estudou-se o efeito na concentração de DNA até os sete dias de vida (Figura 1). Dessa maneira, observou-se que no segundo dia de vida, a concentração de DNA nos dois grupos foi maior $(5,5 \pm 1,1$ e $5,9 \pm 0,8 \mathrm{mg} / \mathrm{g}$ tecido para controle e rbST, respectivamente) comparada com o nascimento (3,6 \pm 0,8 e 4,2 $\pm 1,2$ para controle e rbST, respectivamente). No sétimo dia de vida, a concentração de DNA no jejuno do grupo rbST $(5,1 \pm 1,1 \mathrm{mg} / \mathrm{g}$ tecido) não diferiu das concentrações encontradas ao nascimento e aos dois dias. No grupo controle, a concentração de DNA (6,41 $\pm 0,98 \mathrm{mg} / \mathrm{g}$ tecido), nessa idade, foi maior do que ao nascimento, e também, foi maior comparada com o grupo rbST aos sete dias de vida.

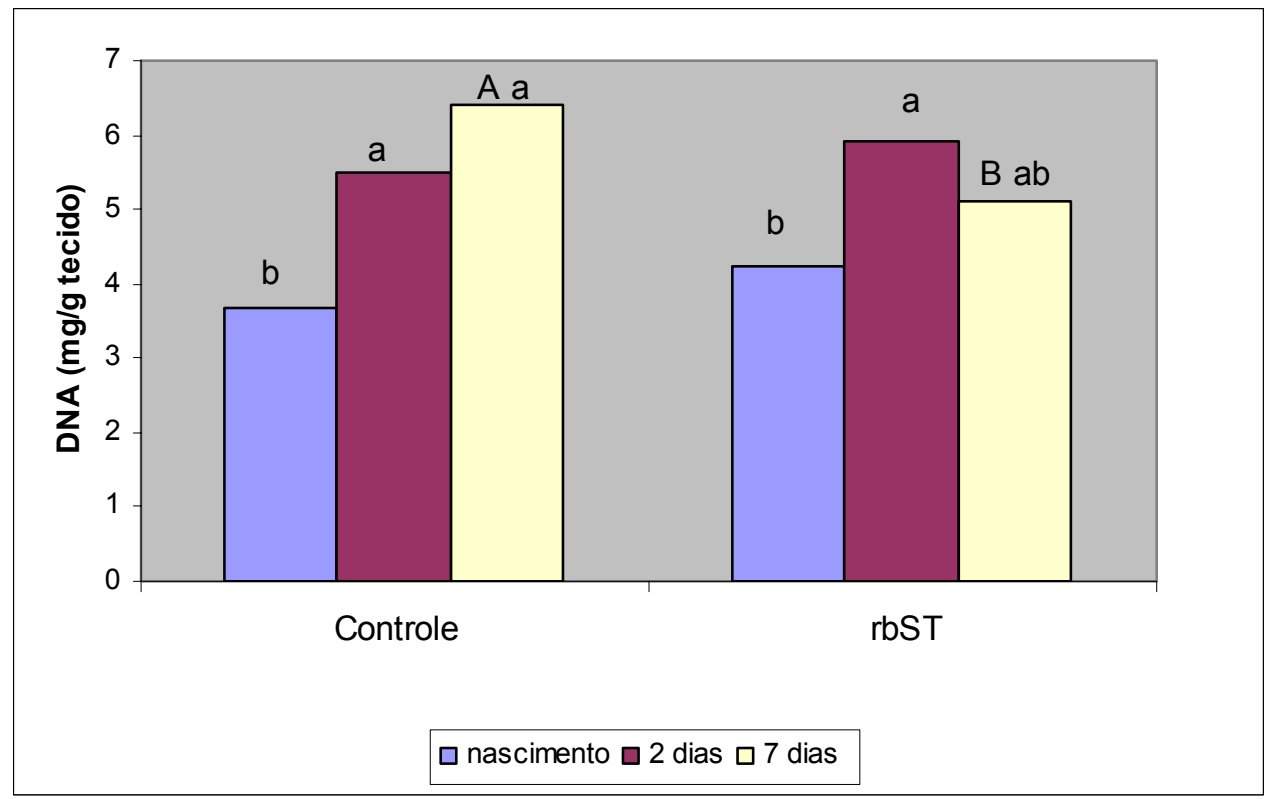

${ }^{\mathrm{ab}}$ Médias seguidas de letras diferentes, dentro de cada grupo, diferem entre si pelo teste Tukey $(P<0,05)$.

${ }^{A B}$ Médias seguidas de letras diferentes, dentro da mesma idade, diferem entre si pelo teste $F(P<0,05)$.

Figura 1 - Concentrações de DNA total no jejuno de bezerros, em diferentes idades, que receberam colostro de vacas controle ou submetidas ao rbST durante o período pré-parto 
A concentração de RNA nos três tecidos não sofreu interação entre os tratamentos, e nem efeito dos grupos, mas apresentou diferenças entre as idades $(P<0,05)$. No fígado e jejuno aos dois dias de vida, a concentração de RNA foi maior comparada com o nascimento (Tabela 3). Já no íleo, essa diferença ocorreu quando os bezerros estavam com sete dias de vida $(P<0,05)$.

A concentração de proteína total no fígado apresentou diferenças entre as idades $(P<0,05)$, sendo maior nos bezerros com dois dias de vida do que nos recém-nascidos (Tabela 3). No jejuno ocorreu interação entre os grupos e as idades ( $P<0,05$; Figura 2). Nos bezerros do grupo rbST, a concentração de proteína foi maior no segundo dia de vida (121,3 $\pm 38,1 \mathrm{mg} / \mathrm{g}$ tecido), comparada com a concentração ao nascimento (90,6 $\pm 21,5 \mathrm{mg} / \mathrm{g}$ tecido) e aos sete dias de vida $(79,7 \pm 10,0 \mathrm{mg} / \mathrm{g}$ tecido). No grupo controle, o aumento na concentração de proteína foi verificado apenas no sétimo dia $(95,4 \pm 26,6$, 98,6 $\pm 21,8$ e 123,7 $\pm 24,2 \mathrm{mg} / \mathrm{g}$ tecido para nascimento, dois e sete dias de vida, respectivamente). O grupo controle também apresentou maior concentração de proteína aos sete dias, comparada com o grupo rbST. 


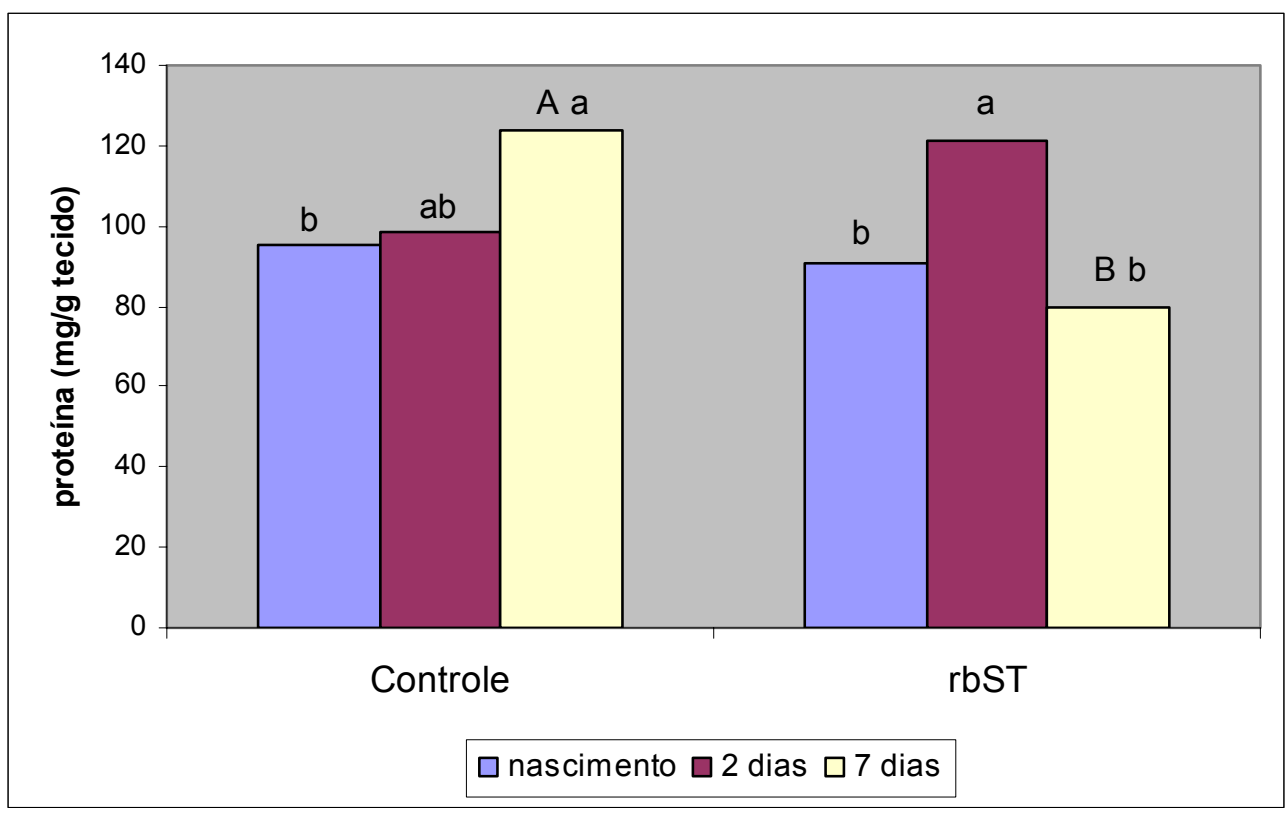

${ }^{a b}$ Médias seguidas de letras diferentes, dentro de cada grupo, diferem entre si pelo teste Tukey $(P<0,05)$.

${ }^{A B}$ Médias seguidas de letras diferentes, dentro da mesma idade, diferem entre si pelo teste $F(P<0,05)$.

Figura 2 - Concentrações de proteína total no jejuno de bezerros, em diferentes idades, que receberam colostro de vacas controle ou submetidas ao rbST durante o período pré-parto

A quantidade de proteína por célula, indicada pela relação proteína/DNA, não demonstrou efeito de interação, nem diferenças entre os grupos e idades nos três tecidos analisados (Tabela 4).

Ao se avaliar a atividade de tradução, pela relação proteína/RNA, verificou-se que o fígado não apresentou efeito dos grupos, enquanto que, nas diferentes idades, a atividade de tradução no fígado dos bezerros com sete dias de vida foi maior comparada aos bezerros com dois dias, não diferindo ao nascimento (Tabela 4). 
Tabela 4. Relações proteína/DNA, proteína/RNA e RNA/DNA no fígado, jejuno e íleo, nas diferentes idades de bezerros que receberam colostro de vacas controle ou submetidas à administração de rbST durante o período pré-parto

\begin{tabular}{|c|c|c|c|c|c|c|c|c|c|}
\hline \multirow{2}{*}{ Tecido } & \multicolumn{2}{|c|}{ Grupos ${ }^{1}$} & \multicolumn{3}{|c|}{ Idade (dias) $)^{2}$} & \multirow{2}{*}{$\mathrm{EPM}^{3}$} & \multicolumn{3}{|c|}{ Probabilidade $^{4}$} \\
\hline & Controle & rbST & 0 & 2 & 7 & & Grupo & Idade & Gr. vs.Id \\
\hline \multicolumn{10}{|c|}{ PROTEÍNA/DNA (mg/mg) } \\
\hline Fígado & 29,2 & 24,5 & 25,6 & 32,0 & 22,9 & 2,62 & NS & NS & NS \\
\hline Jejuno & 22,6 & 19,5 & 23,8 & 21,7 & 17,7 & 1,25 & NS & NS & NS \\
\hline Íleo & 25,6 & 21,7 & 26,2 & 22,9 & 21,8 & 2,74 & NS & NS & NS \\
\hline \multicolumn{10}{|c|}{ PROTEÍNA/RNA (mg/mg) } \\
\hline Fígado & 6,8 & 6,7 & $6,7^{\mathrm{ab}}$ & $6,1^{\mathrm{a}}$ & $7,5^{\mathrm{b}}$ & 0,24 & NS & 0,04 & NS \\
\hline \multicolumn{10}{|c|}{ RNA/DNA (mg/mg) } \\
\hline Fígado & 4,4 & 3,9 & 3,8 & 5,6 & 3,0 & 0,52 & NS & NS & NS \\
\hline Íleo & 3,7 & 2,9 & 3,9 & 3,2 & 2,8 & 0,31 & NS & NS & NS \\
\hline
\end{tabular}

${ }^{\mathrm{ab}}$ Médias seguidas de letras diferentes na mesma linha diferem entre si pelo teste de Tukey $(\mathrm{P}<0,05)$

NS - não significativo

${ }^{1}$ Tratamento: Controle -administração de vitamina E nas vacas, rbST - administração rbST (somatotropina bovina recombinante) nas vacas; ${ }^{2}$ Idade: 0 abate após o nascimento e sem a ingestão do colostro, 2 - abate aos dois dias de vida, 7 - abate aos sete dias de vida; ${ }^{3}$ EPM - erro padrão da média;

${ }^{4}$ Probabilidade: Gr. vs. Id. - interação grupo vs. idade. 
No jejuno e íleo, pode-se verificar efeito de interação $(P<0,05)$ entre aplicação de rbST ou controle e idades (Figuras 3 e 4). No jejuno dos bezerros do grupo rbST, a atividade de tradução aumentou do nascimento $(7,4 \pm 1,3 \mathrm{mg}$ proteína/mg RNA; Figura 3) ao segundo dia (8,9 $\pm 3,4 \mathrm{mg}$ proteína/mg RNA), para em seguida diminuir aos sete dias de idade $(6,0 \pm, 07)$, enquanto que no grupo controle não houve diferença entre as idades $(8,4 \pm 2,5,7,8 \pm 2,2$ e $8,4 \pm$ $1,5 \mathrm{mg}$ proteína/mg RNA, para nascimento, dois e sete dias de idade, respectivamente). Entretanto, o grupo controle apresentou maior atividade de tradução aos sete dias de vida, comparada ao grupo rbST, nessa mesma idade $(\mathrm{P}<0,05)$.

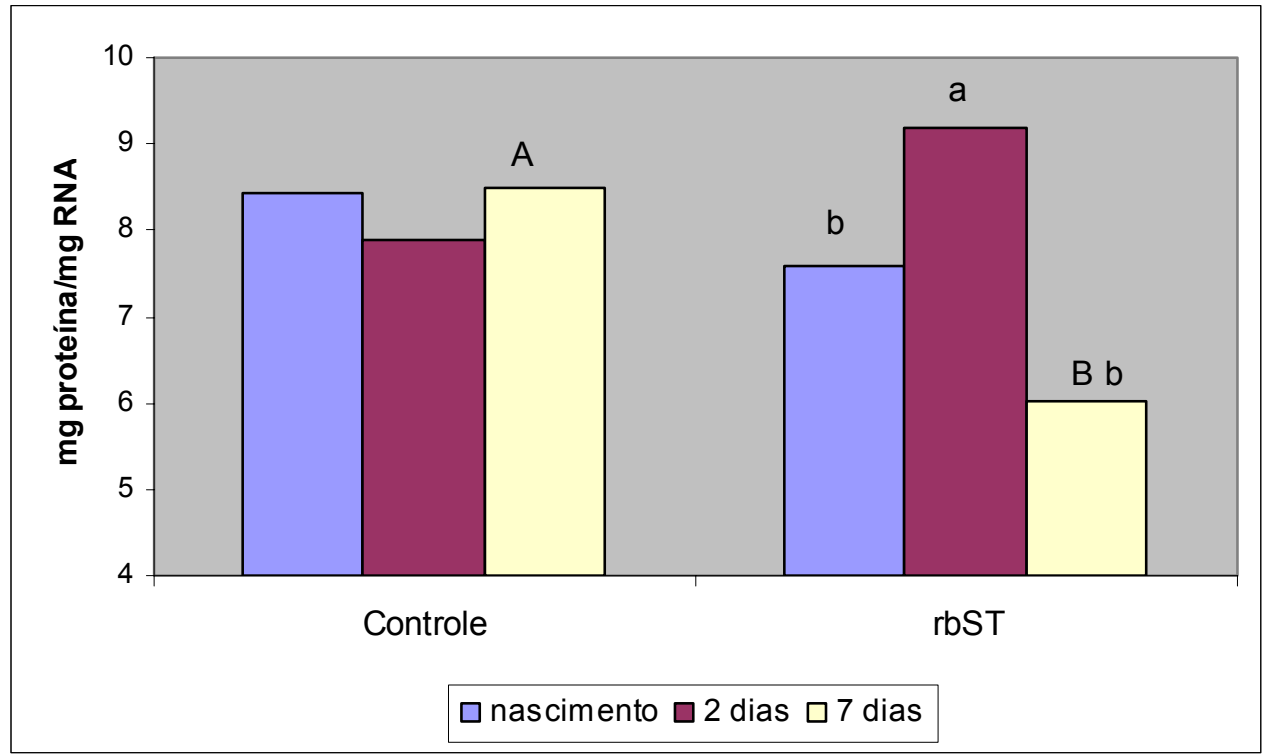

${ }^{a b}$ Médias seguidas de letras diferentes, dentro de cada grupo, diferem entre si pelo teste Tukey $(P<0,05)$.

${ }^{A B}$ Médias seguidas de letras diferentes, dentro da mesma idade, diferem entre si pelo teste $F(P<0,05)$.

Figura 3 - Relação proteína/RNA no jejuno de bezerros, em diferentes idades, que receberam colostro de vacas controle ou submetidas ao rbST durante o período pré-parto 
No íleo, o perfil da atividade de tradução foi semelhante ao jejuno. (Figura 4). No grupo controle, não houve diferenças entre as idades $(5,1 \pm 1,3,6,1 \pm$ 0,9, 6,4 $\pm 1,7 \mathrm{mg}$ proteína/mg RNA, ao nascimento, dois e sete dias de vida, respectivamente). No grupo rbST, a atividade de tradução aumentou do nascimento $(5,8 \pm 1,2 \mathrm{mg}$ proteína/mg RNA) ao segundo dia de vida $(7,6 \pm 1,2$ $\mathrm{mg}$ proteína/mg RNA), diminuindo no sétimo dia de vida $(5,3 \pm 1,2 \mathrm{mg}$ proteína/mg RNA).

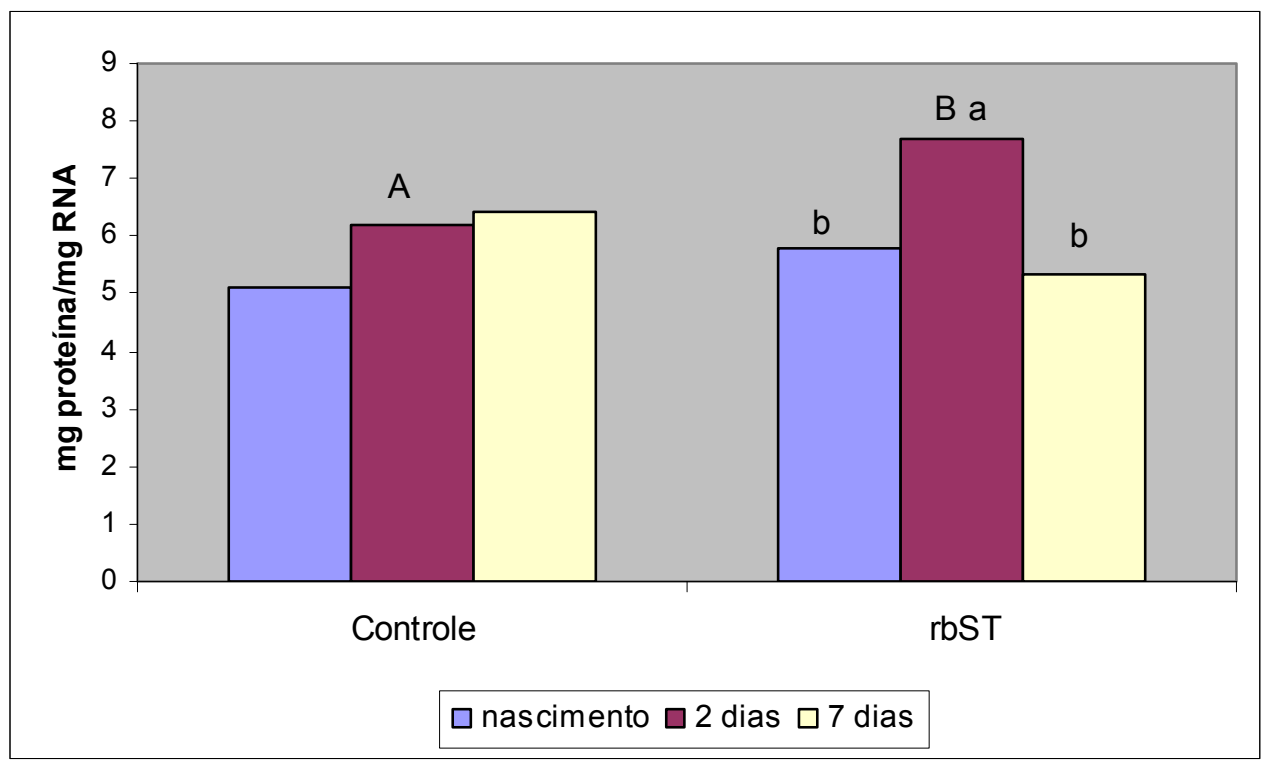

${ }^{a b}$ Médias seguidas de letras diferentes, dentro de cada grupo, diferem entre si pelo teste Tukey $(P<0,05)$.

${ }^{A B}$ Médias seguidas de letras diferentes, dentro da mesma idade, diferem entre si pelo teste $F(P<0,05)$.

Figura 4 - Relação proteína/RNA no íleo de bezerros, em diferentes idades, que receberam colostro de vacas controle ou submetidas ao rbST durante o período pré-parto

Através da relação RNA/DNA obtém-se um indicativo da capacidade de síntese de proteína. Os grupos e as idades não apresentaram efeitos na capacidade de síntese de proteína no fígado e íleo. No jejuno foi encontrada interação entre rbST ou controle e idades ( $P<0,05$; Figura 5). Ao estudar essa interação, verificou-se que os bezerros do grupo controle apresentaram uma diminuição $(P<0,05)$ na capacidade de síntese de proteína no jejuno ao sétimo dia $(2,9 \pm 0,4,2,7 \pm 0,3$ e $2,3 \pm 0,3 \mathrm{mg}$ RNA/mg DNA para nascimento, dois e 
sete dias de vida, respectivamente). Enquanto que, nos animais do grupo rbST, essa diminuição não foi observada $(2,5 \pm 0,3,2,4 \pm 0,4$ e 2,6 \pm 0,2 mg RNA/mg DNA, nascimento, dois e sete dias de vida, respectivamente; Figura 5). Entretanto, nesse último grupo, foi observada maior capacidade de síntese de proteína aos sete dias de vida, comparada com o grupo controle.

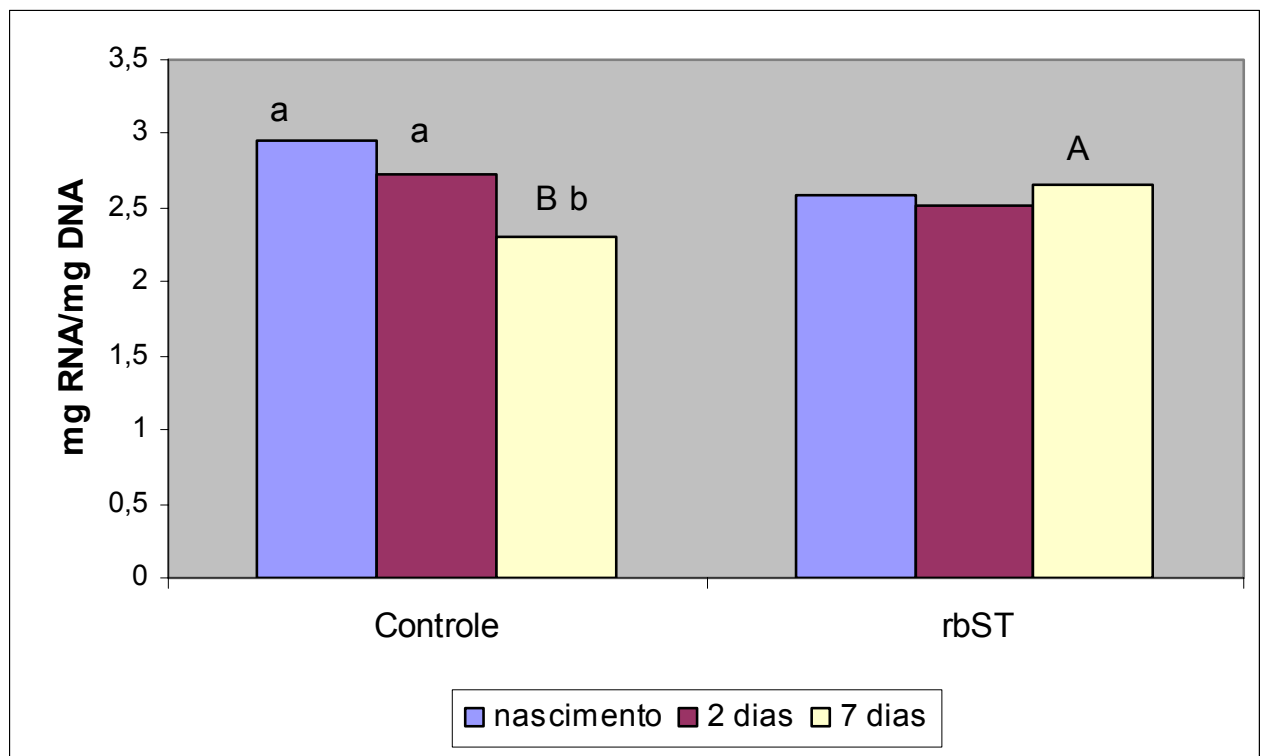

${ }^{a b}$ Médias seguidas de letras diferentes, dentro de cada grupo, diferem entre si pelo teste Tukey $(P<0,05)$.

${ }^{A B}$ Médias seguidas de letras diferentes, dentro da mesma idade, diferem entre si pelo teste $F(P<0,05)$.

Figura 5 - Relação RNA/DNA no jejuno de bezerros, em diferentes idades, que receberam colostro de vacas controle ou submetidas ao rbST durante o período pré-parto

Entre todas as variáveis analisadas, não foram observadas diferenças entre os grupos logo após o nascimento. Isso sugere que a administração de rbST nas mães não apresentou efeito durante o desenvolvimento fetal, em relação às variáveis estudadas e que, também, os efeitos observados nas outras idades sugerem uma resposta à presença do IGF-I no trato intestinal.

Uma das características do final da permeabilidade intestinal, quando ocorre o término da transferência de macromoléculas do intestino para o 
sistema circulatório de ruminantes recém-nascidos, é acompanhada pela presença de enterócitos em diferentes estágios de maturação (Jochims et al., 1994). Durante esse processo, Smeaton \& Simpson-Morgan (1985) observaram aumento na atividade mitótica nas criptas intestinais e proliferação de um tipo diferenciado de célula epitelial, que determina a renovação celular em dois ou três dias após o nascimento de cordeiros. No presente estudo, as concentrações do DNA, no jejuno do grupo controle, aumentaram no segundo dia de vida, coincidindo com o período de transição de geração de células epiteliais intestinais. Esse aumento de DNA indica um processo proliferativo responsável pela hiperplasia da mucosa intestinal. Nesse mesmo período, Bessi et al. (2002a,b), trabalhando com bezerros, encontraram a primeira e segunda população celular, sugerindo uma relação estreita entre a troca e proliferação de células com o final do processo.

Também no grupo controle, os níveis de proteína não aumentaram aos dois dias de vida, indicando que como houve renovação celular, a nova população é composta por uma proporção elevada de células de segunda geração, ou seja, estas células estariam num estágio intermediário de síntese de proteína. A resposta caracterizando a maturidade celular pôde ser observada aos sete dias de vida, com o aumento da concentração de proteína. Durante o período avaliado, a atividade de tradução (proteína/RNA) manteve-se constante. A diminuição da relação RNA/DNA, que refletiria uma queda da capacidade celular de síntese de proteína, seria resultado de uma diferença da população com proporção reduzida de células de primeira e até da segunda geração. Todas essas observações, encontradas no grupo controle, estariam relacionadas com as atividades de proliferação celular e apoptose.

O fornecimento do colostro, de vacas que receberam rbST, promoveu algumas diferenças na mucosa intestinal, comparadas com o grupo controle. A concentração de DNA aos dois dias de vida aumentou, refletindo a proliferação celular que ocorre no período. Mas, aos sete dias de vida, o DNA declinou para 
níveis intermediários, comparando-se nascimento e dois dias. Uma das sugestões propostas para essa observação seria resultado da relação entre a taxa de proliferação celular e apoptose inferiores.

A concentração de proteína no grupo controle aumentou apenas no sétimo dia de vida dos bezerros. Já no grupo rbST, houve aumento de proteína no segundo dia de vida. Esse resultado relacionado com o obtido na concentração de DNA, sugere um comportamento de célula madura, acompanhado da diminuição da apoptose. Uma vez que, esta última está relacionada com a degradação protéica, a sua diminuição poderia aumentar a meia vida dos enterócitos, o que, conseqüentemente, acarretaria em acúmulo da proteína na mucosa. Outra possibilidade de contribuição para esse acúmulo de proteína estaria relacionada com maiores atividades de enzimas digestivas no epitélio intestinal. Bessi et al. (2002a,b) observaram reação de enzima fosfatase ácida, que indica a presença de enzimas hidrolíticas, nas membranas apicais das células e reação em lisossomos no jejuno de bezerros aos três dias de vida, não sendo observada a mesma reação ao nascimento e após a ingestão do colostro. Blättler et al. (2001) observaram diferenças nas atividades das enzimas digestivas e absorção de xilose, que é um indicador de absorção, sendo maiores nos bezerros que ingeriram colostro comparado com sucedâneo.

No sétimo dia de vida, a população celular madura pode estar entrando no processo apoptótico, causando uma diminuição na síntese protéica na mucosa do jejuno. Essas mudanças também foram refletidas na atividade de tradução (proteína/RNA), que foi maior no segundo dia e se igualou aos níveis iniciais no sétimo dia, sugerindo, novamente, maturidade da competência absortiva das células. A capacidade de síntese de proteína (RNA/DNA) foi semelhante entre as idades, possivelmente, a composição celular da população seria similar, indicando a manutenção de proporção significativa de células com características de maturidade absortiva. 
Analisando essas variáveis, isoladamente, dentro de cada idade, podemos justificar as inferências propostas. As concentrações de DNA, proteína e atividade de tradução no grupo rbST foram menores do que no grupo controle, aos sete dias de vida, confirmando a hipótese de diminuição da apoptose após a ingestão de colostro, e no sétimo dia as células estariam iniciando o processo de degradação de DNA e proteína. Enquanto que no grupo controle, já se encontraria uma nova geração de células.

De acordo com Rauprich et al. (2000), o aumento da concentração do DNA no intestino de recém-nascidos tem uma forte relação com a presença de peptídios bioativos presentes no colostro. No entanto, nem todos os trabalhos conseguiram obter respostas positivas em relação à concentração de DNA no intestino de animais que receberam colostro. Com esse fato, novo papel tem sido sugerido ao IGF-I, que seria o de reduzir a apoptose (Blättler et al., 2001).

As respostas apresentadas, com base nos resultados do presente trabalho, estão de acordo com as observações encontradas por Winesett et al. (1995). Estes autores relataram que a presença de nutrientes no trato possa alterar a taxa de renovação celular. E também, segundo Potten et al. (1997), além da proliferação celular, a apoptose também é um regulador do número de células, que pode ser inibida pela presença do IGF-I. Aliado a essa característica do IGF-I, estudos têm observado que a administração do IGF-I, simultaneamente, com a nutrição parenteral total (NPT), pode prevenir ou reverter a atrofia da mucosa, pela estimulação da proliferação dos enterócitos e diminuição da apoptose, mantendo a integridade do tecido (Peterson et al., 1997; Dahly et al., 2002).

Resultados semelhantes ao presente estudo foram encontrados por Blättler et al. (2001), os quais também observaram a redução da apoptose nas células intestinais de bezerros que receberam colostro por três dias, comparados com os que receberam apenas no primeiro dia de vida. No intestino delgado não foram observadas diferenças nas concentrações de DNA 
e RNA entre os tratamentos. Entretanto, a concentração média de proteína foi maior no jejuno dos animais que receberam colostro por três dias. Os autores verificaram que prolongando o consumo do colostro, a proliferação celular da mucosa foi reduzida no oitavo dia de vida. Porém, como não houve efeitos significativos nas concentrações de DNA no trato intestinal, a densidade celular não foi influenciada. Esta redução da apoptose decorrente do consumo de colostro, possivelmente mediada pelos fatores de crescimento, também foi observada por Mylonas et al. (2000) e Playford et al. (2000).

No presente estudo, não foi observada maior proliferação celular nos animais do grupo rbST. Provavelmente, a quantidade de IGF-I ingerida por esse grupo pode não ter sido suficiente para aumentar a proliferação celular da mucosa intestinal. Segundo Ma \& Xu (1997), a ingestão de IGF-I em baixas concentrações estimulam a maturação das células epiteliais, enquanto que quantidades elevadas são necessárias para estimular o crescimento intestinal. Os autores observaram que o fornecimento de rhIGF-I, oralmente, para ratos, aumentou a concentração de proteína no intestino delgado, mas não encontraram efeitos na concentração de DNA e na relação proteína/DNA que é um indicador de volume celular, sugerindo a maturação dos enterócitos.

Como já discutido, uma das características que apontam para a maturação do epitélio intestinal é o aumento da concentração de proteína, sem alterações nos níveis de DNA. Simmen et al. (1990) também observaram essas respostas quando forneceram lactose, colostro ou leite para leitões recémnascidos. Os autores não verificaram diferenças nas concentrações de DNA no intestino delgado, entretanto, as concentrações de proteína, RNA e a relação RNA/DNA foram maiores nos animais que ingeriram colostro ou leite comparadas à lactose.

Baumrucker et al. (1994) compararam o fornecimento de sucedâneo enriquecido com rhIGF-I $(750 \mathrm{ng} / \mathrm{ml})$ por sete dias e colostro $(665 \mathrm{ng} / \mathrm{mL})$ por dois dias para bezerros recém-nascidos. Os autores verificaram que a 
incorporação de rhIGF-I na dieta de bezerros acelerou a síntese de DNA no intestino delgado. Já, Bühler et al. (1998) demonstraram que a administração do IGF-I, tanto injetável quanto via oral, falhou em demonstrar os efeitos promotores de crescimento no intestino delgado, como o aumento do DNA e da proteína. Os autores atribuíram essa falta de resposta à necessidade de se aumentar em níveis suprafisiológicos o IGF-I sintético, mas quando fornecido oralmente, este também poderia ter sido destruído pelas proteases intestinais, mais facilmente que o IGF-I do colostro, contribuindo o fato de não estar ligado às IGFBPs. Essa observação já havia sido comprovada por Burrin et al. (1996), os quais demonstraram que o IGF-I fornecido em doses suprafisiológicas pode aumentar o crescimento do intestino delgado, estimulando a proliferação das células presentes nas criptas, sendo acompanhado com aumento do peso e das concentrações de DNA e proteína, no jejuno e íleo de leitões que receberam sucedâneo enriquecido com rhIGF-I (3,5 mg/kg de peso vivo) comparadas ao grupo controle (colostro com $100 \mu \mathrm{g}$ de IGF-l/kg peso vivo).

Como relacionado e discutido, a maioria dos trabalhos, bem como o presente estudo, observou aumento na concentração de proteína no intestino. Esse aumento pode ser atribuído à combinação de três fatores. Primeiro, a endocitose de imunoglobulinas no colostro, principalmente IgG, e a grande quantidade de proteínas presente no mesmo. A concentração média de IgG no colostro e nas subseqüentes secreções lácteas não diferiram entre os tratamentos. No colostro, a média de lgG encontrada foi de $119,60 \mathrm{mg} / \mathrm{mL}$, e do segundo ao sétimo dia pós-parto, as concentrações de IgG decresceram para 28,93 e $8,92 \mathrm{mg} / \mathrm{mL}$, respectivamente (Pauletti, 2003). A capacidade de absorção das imunoglobulinas é limitada em bezerros recém-nascidos, uma vez que o epitélio intestinal torna-se progressivamente impermeável, cessando a absorção entre 24 e 36 horas após o nascimento (Brambell, 1958; Lecce \& Morgan, 1962; Lecce, 1973; Besser et al., 1991; Quigley et al., 1995). Desse modo, sugere-se que o intestino delgado dos bezerros com dois dias de vida, ainda apresentava vacúolos intracelulares com proteínas nos enterócitos. 
Entretanto, essa hipótese não pode ser totalmente aplicada aos resultados observados, considerando que nos animais do grupo controle não houve aumento da concentração de proteína aos dois dias de vida. O aumento observado no grupo rbST, poderia ser reflexo da maturação celular $(P=0,11)$.

Como segundo fator que se aplicaria às respostas obtidas, o colostro aumenta as concentrações intestinais de RNA e síntese de proteína pelos enterócitos, também considerado por Simmen et al. (1990). Terceiro, a maior quantidade de DNA às 48 horas indica que o colostro estimulou proliferação das células nas criptas, condição que também está de acordo com Burrin et al. (1992).

Segundo Patureau-Mirand et al. (1990), o aumento do conteúdo de proteína total no intestino em resposta à ingestão de colostro resulta de aumento em ambas síntese endógena e absorção de proteína do colostro. Os autores verificaram correlação positiva entre consumo de proteína e a taxa de síntese de proteína no fígado. De acordo com essa hipótese, recém-nascidos que ingerem colostro consomem mais proteína e, portanto, absorvem mais aminoácidos, que ficam disponíveis para síntese protéica, especialmente no intestino e fígado (Burrin et al., 1992). Estas condições também foram verificadas no presente trabalho, indicando que o fornecimento do colostro, independente do tratamento, aumentou a concentração de proteína no fígado, aos dois dias de vida (Tabela 4).

Assim, o IGF-I se apresenta como um importante participante da maturação celular, com um papel determinante no comportamento da primeira geração de enterócitos. Outro aspecto significativo nesse processo diz respeito ao nível de IGF-I que pode definir diferentes respostas na maturação e proliferação. 


\subsubsection{Durante o desenvolvimento neonatal}

No presente trabalho observou-se que as concentrações de DNA e RNA ( $\mathrm{mg} / \mathrm{g}$ de tecido) no jejuno e íleo aumentaram com a idade, e a concentração de proteína aumentou no fígado e no jejuno. Em outro segmento do projeto, Pauletti (2003) observou que o peso do trato gastrintestinal demonstrou respostas semelhantes às variáveis DNA e RNA, ou seja, houve aumento aos dois dias de vida.

Diferentes padrões relacionados com idade e aumento de DNA eram esperados nos dois segmentos intestinais, caracterizando diferenças espaciais e temporais nas taxas de proliferação dos enterócitos durante as primeiras 48 horas de vida. Um fato que pode afetar esta avaliação é a presença de bactérias que rapidamente colonizam o intestino após o nascimento, que também podem contribuir com uma fração desconhecida de DNA no intestino (Swords et al. 1993).

Com relação ao fígado, também se verificou aumento de peso aos dois dias de vida dos bezerros $(734,6 \pm 147,7 \mathrm{~g}$ e $894,6 \pm 166,6 \mathrm{~g}$, ao nascimento e aos dois dias de vida respectivamente; Pauletti, 2003), porém, a concentração de DNA não seguiu o mesmo acréscimo. No entanto, a concentração de RNA e proteína acompanhou o aumento de peso do fígado com o aumento da idade dos bezerros, refletindo também no aumento da síntese protéica.

Cordano et al. (2000) também observaram maior concentração de RNA, bem como do DNA total, no fígado de bezerros recém-nascidos, comparados com animais em crescimento e adultos. Segundo os autores, esses resultados eram esperados, pois refletiram maior atividade mitogênica e protéica nos animais jovens. As menores concentrações de proteína total e a menor relação proteína:RNA total nos recém-nascidos, comparadas aos bovinos adultos, expressaram menores taxas de tradução. $O$ aumento da taxa de tradução (mg 
proteína/mg RNA, Tabela 4) no fígado, obtido no presente estudo, pode ser observado do segundo aos sete dias de vida.

Paralelamente aos diversos autores que relacionaram o aumento da proteína no trato intestinal e da taxa de síntese de proteína no fígado de recémnascidos ao consumo de colostro, e conseqüentemente, aos fatores de crescimento, segundo Burrin et al. $(1992,1995)$, o fator predominante afetando a resposta anabólica da proteína nos tecidos viscerais poderia ser o consumo de nutrientes e talvez a associação de processos fisiológicos associados com a alimentação.

Zhang et al. (1997), investigando as mudanças que ocorrem no intestino de leitões recém-nascidos que ingeriram colostro até 24 horas de vida, verificaram que a concentração de proteína na mucosa intestinal aumentou $126 \%$ durante as primeiras seis horas após o nascimento. Após 12 horas, a quantidade total de DNA na mucosa de todo o intestino foi $177 \%$ maior.

\subsection{Avaliação da expressão do gene do IGF-I pela abundância de RNAm}

Os resultados dos efeitos dos tratamentos na quantificação do RNAm do IGF-I, estão apresentados como número de moléculas/mg de tecido, nas Tabelas 5 e 6 . As concentrações do RNAm do IGF-I, no fígado dos bezerros, apresentou interação entre os grupos e idades $(P<0,05$; Tabela 5$)$. 
Tabela 5. Expressão do RNAm do IGF-I no fígado de bezerros, em diferentes idades, que receberam colostro de vacas controle ou submetidas ao rbST durante o período pré-parto

\begin{tabular}{|c|c|c|c|c|c|c|c|}
\hline \multirow{2}{*}{ Grupo ${ }^{1}$} & \multicolumn{3}{|c|}{ Idade (dias) ${ }^{2}$} & \multirow{2}{*}{$\mathrm{EPM}^{3}$} & \multicolumn{3}{|c|}{ Probabilidade $^{4}$} \\
\hline & 0 & 2 & 7 & & 0 & 2 & 7 \\
\hline \multicolumn{8}{|c|}{$\mathrm{n}^{0} \mathrm{~mol} / \mathrm{mg} \mathrm{tec}{ }^{5}$} \\
\hline Controle & $537,0^{\mathrm{B}}$ & 325,7 & $269,1^{\mathrm{B}}$ & \multirow{2}{*}{1730} & \multirow{2}{*}{0,02} & \multirow{2}{*}{ NS } & \multirow{2}{*}{0,01} \\
\hline $\mathrm{rbST}$ & $10839,2^{\mathrm{Aa}}$ & $346,7^{b}$ & $10023,3^{\mathrm{Aa}}$ & & & & \\
\hline
\end{tabular}


Análise do RNAm do IGF-I no fígado, logo após o nascimento, apresentou maior expressão do gene do IGF-I $(P<0,05)$ nos bezerros provenientes das mães que receberam rbST, comparada com o grupo controle (Tabela 5). Esta resposta sugere um reflexo de estímulo direto deste hormônio sobre o feto. Embora de acordo com Watches et al. (1998), o hormônio de crescimento materno não atravesse a placenta, segundo Burton et al. (1994), pode ocorrer estímulo da secreção de IGF-I pelo feto. Correlações positivas já foram relatadas entre as concentrações séricas de IGF-I da mãe e feto no final da gestação (Carr et al., 1995). Nas avaliações efetuadas por Pauletti (2003) não foi verificada relação sérica do IGF-I entre vaca e bezerro. A razão para esta falta de resposta nos bezerros poderia ser aquela proposta por Watches et al. (1998) relacionada à formação do placentoma que funciona como barreira física evitando que o IGF-I complexado às IGFBPs penetre na circulação fetal.

A administração do rbST, 35 dias pré-parto, pode ter induzida uma maior disponibilidade de nutrientes na circulação materna, e estes teriam sido direcionados ao feto. Neste sentido, Bauman \& Currie (1980) verificaram que vacas quando estão, simultaneamente, lactando e prenhas, a prioridade dos nutrientes é direcionada para o feto, especialmente no final da gestação. A presença de maior quantidade de nutrientes na circulação fetal, pode ter estimulado a expressão do IGF-I no fígado observada ao nascimento. Uma outra hipótese seria aquela sugerida por Watches et al. (2002), relacionando à disponibilidade do IGF-I sérico da mãe em influenciar o crescimento da placenta, permitindo a entrada de maior quantidade de nutrientes para o feto.

A limitação de nutrientes para a circulação fetal foi estudada por Osgerby et al. (2002). Estes autores observaram que ovelhas gestantes, mantidas em restrição alimentar, apresentaram menores concentrações de IGF-I e glucose séricos. Esta diminuição da disponibilidade de nutriente para o feto, também refletiu na diminuição do IGF-I sérico fetal, no terço final da gestação. Quando ovelhas na metade da gestação estavam em restrição alimentar, McMullen \& 
Wathes (2003) observaram queda no IGF-I sérico materno, mas não de glucose, enquanto que a concentração sérica do IGF-I no feto manteve-se inalterada.

O declínio da concentração do RNAm do IGF-I no fígado, verificado aos dois dias de vida, indica que os níveis observados ao nascimento são decorrentes do efeito do rbST na vaca durante a gestação, e que esse efeito não se prolongou aos dois dias. O aumento observado no sétimo dia de vida, igualando aos níveis do nascimento, sendo também maior comparado ao grupo controle $(P<0,05)$, pode ser explicado pela ingestão do colostro dessas vacas. Conforme já sugerido, a maturidade dos enterócitos ao dois dias permitiria que esses animais apresentassem maior capacidade absortiva no jejuno e, portanto, responderiam com maior expressão do IGF-I no fígado.

Cordano et al. (2000) observaram maiores concentrações séricas de IGF-I, refletidas pela maior expressão do mesmo no fígado de bezerros com oito dias de vida que receberam colostro, comparados com os que receberam sucedâneo. Essas respostas corroboram com a hipótese de maior expressão do IGF-I no fígado, também verificado no presente trabalho, que pode ter sido influenciada pelo maior aporte de nutrientes, como conseqüência de um aumento do crescimento do trato intestinal e maior habilidade absortiva, provenientes de fornecimento de componentes específicos do colostro. Vários trabalhos comparando a ingestão do colostro com a ingestão de água, sucedâneo ou leite também observaram aumento do IGF-I circulante (Baumrucker \& Blum, 1994; Baumrucker et al., 1994; Vacher et al., 1995; Odle et al., 1996; Burrin, 1997; Wester et al., 1998).

Bezerros recém-nascidos já apresentam o eixo somatotrópico funcional, mas ainda imaturo (Hammon \& Blum, 1997). Os dados observados nos animais do grupo controle demonstraram que até o sétimo dia de vida não houve aumento na expressão do RNAm do IGF-I no fígado. Menores concentrações séricas e da expressão do IGF-I no fígado de bezerros com oito dias de vida 
comparadas com animais em fase posterior de crescimento foram observadas por Cordano et al. (2000), demonstrando que o eixo somatotrópico passa por uma fase de amadurecimento nesse período.

O gene do RNAm do IGF-I no fígado é expresso em níveis 10 a 1000 vezes maiores que os encontrados em outros tecidos. A expressão hepática aumenta consideravelmente no fígado na fase pós-natal, coincidindo com os aumentos dos níveis do IGF-I sérico, que se torna mais importante com a idade. Em bovinos, esses aumentos estão estritamente relacionados ao aumento na massa corpórea (LeRoith et al., 2001). Recém-nascidos também apresentam baixa concentração de receptores da ST no fígado, indicando que ST não tem influência dominante na produção do IGF-I na fase perinatal (Breier et al., 1988).

Em vários trabalhos, os níveis de IGF-I circulante foram correlacionados com a abundância do RNAm do IGF-I no fígado. Pauletti (2003) observou queda de $60 \%$ na concentração do IGF-I sérica até o segundo dia de vida, e ao sétimo dia de vida as concentrações se igualaram às do nascimento. Os níveis do RNAm do IGF-I dos bezerros do grupo rbST apresentaram perfil semelhante em relação às concentrações séricas, entretanto, o grupo controle não apresentou tal comportamento. Mas, ao analisar a correlação entre o IGF-I sérico e o RNAm durante a primeira semana de vida, observou-se correlação significativa $(P<0,05)$, com valor médio de $r=0,52$ para o grupo controle e $r=0,55$ para o grupo rbST.

Lee et al. (1993) não observaram diferenças na expressão do gene do IGF-I no fígado de leitões desde recém-nascidos até 42 dias de vida, enquanto que foram observados aumentos na concentração sérica do IGF-I. Os autores atribuíram esse fato ao menor desaparecimento do IGF-I sérico ao invés de um aumento da produção deste pelo fígado. Schober et al. (1990) também não verificaram diferenças na expressão do RNAm do IGF-I no fígado e intestino com o avanço da idade dos leitões (nascimento até 21 dias). No estudo de 
Rhoads et al. (1994), não foram observadas diferenças na expressão do gene do IGF-I no fígado de cordeiros abatidos com idades entre 12 e 38 dias.

Diferentemente do que ocorre com bovinos, estudos com suínos demonstraram que não há correlação estreita entre IGF-I circulante com o gene relacionado à sua expressão no início do desenvolvimento pós-natal de leitões (Lee et al., 1993; Matteri et al., 2000). A falta de identificação dessa associação, em suínos em desenvolvimento, pode estar relacionada a contribuições não determinadas dos diversos tecidos produtores de IGF-I para o "pool" circulante de IGF-I. Matteri et al. (2000) observaram reduções nas concentrações do IGF-I circulante logo após a desmama de leitões, mas as quantidades correspondendo aos RNAm no fígado e músculo não foram afetadas da mesma maneira.

No jejuno e íleo, não foram observadas interações entre os grupos e idades, e nem diferenças nos efeitos principais na expressão do RNAm do IGF-I (Tabela 6).

A presença de expressão do IGF-I no intestino dos bezerros sugere que, além do IGF-I fornecido no colostro e da produção endócrina pelo fígado, o intestino também é exposto ao IGF-I por mecanismo autócrino e/ou parácrino. A importância do IGF-I produzido localmente para o crescimento intestinal é atribuída pela associação entre os níveis do RNAm do IGF-I e de seu receptor com a proliferação celular nas criptas do intestino delgado (Blättler et al., 2001). A síntese do IGF-I no intestino pode ainda estar relacionada ao aumento da proliferação celular e/ou diminuição da apoptose das células intestinais. Contudo, como no presente trabalho não foram observadas diferenças na expressão do gene do IGF-I, a possível maturação celular observada no jejuno pode ter sido efeito do acréscimo do IGF-I no colostro das vacas administradas com rbST, e não da síntese autócrina e/ou parácrina desse peptídeo. 
Tabela 6. Expressão do RNAm do IGF-I jejuno e íleo, nas diferentes idades de bezerros que receberam colostro de vacas controle ou submetidas à administração de rbST durante o período pré-parto

\begin{tabular}{|c|c|c|c|c|c|c|c|c|c|}
\hline \multirow{2}{*}{ Tecidos } & \multicolumn{2}{|c|}{ Grupo ${ }^{1}$} & \multicolumn{3}{|c|}{ Idade (dias) $^{2}$} & \multirow{2}{*}{$\mathrm{EPM}^{3}$} & \multicolumn{3}{|c|}{ Probabilidade $^{4}$} \\
\hline & Controle & rbST & 0 & 2 & 7 & & Grupo & Idade & Gr. vs. Id. \\
\hline \multicolumn{10}{|c|}{$\mathrm{n}^{0} \mathrm{~mol} / \mathrm{mg} \mathrm{tec}{ }^{5}$} \\
\hline Jejuno & 0,11 & 0,10 & 0,14 & 0,10 & 0,11 & 0,02 & NS & NS & NS \\
\hline Íleo & 12,5 & 5,4 & 10,2 & 5,4 & 11,2 & 6,29 & NS & NS & NS \\
\hline
\end{tabular}




\subsection{Avaliação da expressão do gene do receptor tipo I pela abundância de RNAm}

Na Tabela 7 estão apresentados os resultados da quantificação do RNAm do receptor tipo I, na concentração expressa por número de moléculas/mg de tecido. A expressão do gene do receptor tipo I demonstrou apenas efeito nas diferentes idades no jejuno e íleo $(P<0,05)$.

A presença de expressão do gene do receptor tipo I no fígado indicou que, além desse órgão ser a fonte principal do IGF-I circulante, o mesmo também pode sofrer estímulos do IGF-I. A ausência de diferenças nos níveis do RNAm do receptor no fígado relaciona-se o fato que durante a primeira semana de vida de bezerros, o eixo somatotrópico ainda não está maduro. Georgieva et al. (2003) também não observaram diferenças na expressão do receptor do IGF-I, assim como do hormônio de crescimento, no fígado de bezerros durante a primeira semana de vida, enquanto que em leitões a expressão do receptor tipo I no fígado diminuiu com a idade (Lee et al., 1993). 
Tabela 7. Expressão do RNAm do receptor tipo I no fígado, jejuno e íleo, nas diferentes idades de bezerros que receberam colostro de vacas controle ou submetidas à administração de rbST durante o período préparto

\begin{tabular}{|c|c|c|c|c|c|c|c|c|c|}
\hline \multirow{2}{*}{ Tecidos } & \multicolumn{2}{|c|}{ Tratamento $^{1}$} & \multicolumn{3}{|c|}{ Idade (dias) ${ }^{2}$} & \multirow{2}{*}{$\mathrm{EPM}^{3}$} & \multicolumn{3}{|c|}{ Probabilidade $^{4}$} \\
\hline & Controle & rbST & 0 & 2 & 7 & & Grupo & Idade & Gr. vs Id. \\
\hline \multicolumn{10}{|c|}{$\mathrm{N}^{0} \mathrm{~mol} / \mathrm{mg} \mathrm{tec}{ }^{5}$} \\
\hline Fígado & 712,8 & 1578,2 & 970,9 & 667,7 & 1956,7 & 760 & NS & NS & NS \\
\hline Jejuno & 1,3 & 1,1 & $2,5^{\mathrm{b}}$ & $1,1^{\mathrm{ab}}$ & $0,5^{\mathrm{a}}$ & 0,8 & NS & 0,04 & NS \\
\hline Ileo & 12,9 & 18,4 & $40,6^{a}$ & $3,4^{b}$ & $9,1^{\mathrm{b}}$ & 12,3 & NS & 0,03 & NS \\
\hline
\end{tabular}

${ }^{\text {ab }}$ Médias seguidas de letras diferentes na mesma linha diferem entre si pelo teste Tukey $(P<0,05)$

NS - não significativo

${ }^{1}$ Grupo: Controle -administração de vitamina E nas vacas, rbST - administração de rbST (somatotropina bovina recombinante) nas vacas; ${ }^{2}$ Idade: 0 abate logo após o nascimento e sem a ingestão do colostro, 2 - abate aos dois dias de vida, 7 - abate aos sete dias de vida; ${ }^{3}$ EPM - erro padrão das médias; ${ }^{4}$ Probabilidade: Gr. vs. Id. - interação grupo vs. Idade; ${ }^{5} \mathrm{n}^{\circ} \mathrm{mol} / \mathrm{mg}$ tec - número de moléculas $\mathrm{X} 10^{3} / \mathrm{mg}$ de tecido 
A maioria dos trabalhos que observaram diferenças no desenvolvimento intestinal de recém-nascidos, utilizando IGF-I sintético oral comparado com colostro, utilizaram doses em concentrações 10 a 20 vezes maiores do que as do IGF-I encontradas no colostro (Xu et al., 1994; Vacher et al., 1995; Donovan et al.,1997; Houle et al., 1997; Ma \& Xu, 1997). No presente estudo, a quantidade de IGF-I no colostro das vacas que receberam rbST foi $30 \%$ maior comparada ao das vacas controle. Esse aumento, provavelmente, não teria sido suficiente para induzir efeitos significativos na expressão do IGF-I e de seu receptor no intestino.

Muito se tem discutido sobre a importância da densidade de nutrientes que possa afetar a expressão do IGF-I em vários tecidos, mas seus efeitos na expressão do receptor são conflitantes. Georgiev et al. (2003) não observaram diferenças no número de receptores ou no RNAm do receptor tipo I no intestino de bezerros com oito dias de vida, que foram alimentados com colostro por três dias ou "pool" de colostro, ou ainda sucedâneo apresentando a mesma densidade de nutrientes do colostro, mas com ausência de fatores de crescimento. Já, Hammon \& Blum (2002) observaram que o número de receptores aumentou com o fornecimento de colostro por três dias para bezerros recém-nascidos. $O$ fornecimento de sucedâneo com menor concentração de nutrientes causou diminuição no número de receptores do IGF-I e insulina na mucosa intestinal.

Baumrucker et al. (1994) verificaram que a adição de rhIGF-I em sucedâneo aumentou a ocorrência dos receptores tipo I quando comparado com colostro, indicando que o IGF-I na dieta possa regular o receptor na mucosa intestinal, mas quando compararam colostro com sucedâneo essa característica não foi observada. 
A expressão do gene do receptor no intestino está ligada à idade. No jejuno houve uma queda da abundância do RNAm do receptor tipo I entre o nascimento e o sétimo dia de vida $(P<0,05)$, mas no íleo, essa diminuição pôde ser verificada no segundo dia (Tabela 7). A maior concentração de RNAm do receptor, sem diferença na expressão do RNAm do IGF-I no intestino durante o período perinatal, sugere que o intestino do animal está preparado para receber - IGF-I presente no colostro, indicando a presença de um sincronismo biológico. Endossando esta proposta, encontramos os resultados obtidos por Georgiev et al. (2003), que observaram que bezerros prematuros ao nascer já apresentam expressão do gene do receptor do IGF-I no tecido intestinal na mesma magnitude daqueles provenientes de gestações normais.

A diminuição da expressão do receptor tipo I no intestino de bezerros abatidos com oito dias de vida comparada com aqueles abatidos logo após o nascimento foi também observada por Georgieva et al. (2003). Já, Georgiev et al. (2003) não observaram diferenças na expressão do RNAm do receptor tipo I nem no número de receptores na primeira semana de vida de bezerros.

Em suínos, a presença de receptores também diminui com a idade. Leitões recém-nascidos apresentaram maior número de receptores no jejuno do que os animais desmamados, mas a afinidade do receptor em ligar-se ao IGF-I manteve-se a mesma (Morgan et al., 1996). Schober et al. (1990) também verificaram declínio na quantidade de receptores do nascimento até o quinto dia de vida, tendo aumentado aos 21 dias de idade, enquanto que a expressão do RNAm do receptor do IGF-I no intestino não apresentou diferenças com a idade dos leitões. Os autores sugeriram que a diferença nas respostas em relação ao número de receptores e a expressão do receptor estaria relacionada à técnica de hibridização e marcação radioativa do receptor na mucosa intestinal, a qual não contabilizava aqueles receptores já ligados às moléculas do IGF-I provenientes do colostro. 
Assim como para os autores Schober et al. (1990), Morgan et al. (1996) e Georgieva et al. (2003), a idade se constitui num fator determinante influindo na expressão do receptor do IGF-I no intestino. No presente estudo, a idade determinou a diminuição da expressão do receptor nos segmentos do intestino delgado avaliados. 


\section{CONCLUSÕES}

A ingestão de colostro, proveniente de vacas que receberam rbST préparto, determinou alterações no estágio de maturação das células do jejuno de bezerros.

A utilização de rbST pré-parto determinou aumento da expressão do IGF-I no fígado de bezerros ao nascimento.

Ao nascimento, o intestino dos bezerros apresentou condição de resposta à presença do IGF-I proveniente do colostro.

Níveis mais elevados de IGF-I no colostro não alteraram a expressão do IGF-I e de seu receptor no jejuno e íleo. 


\section{REFERÊNCIAS BIBLIOGRÁFICAS}

ABBOTT, A.M.; BUENO, R.; PEDRINI, M.T.; MURRAY, J.M.; SMITH, R.J. Insulin like growth factor I receptor gene structure. The Journal of Biological Chemistry, v.267, p.10759-10763, 1992.

BAKER, J.; LIU, J.P.; ROBERTSON, E.J.; EFSTRATIADIS, A. Role of insulinlike growth factors in embryonic and postnatal growth. Cell, v.75, p.73-82, 1992.

BAUMAN, D.E.; CURRIE, W.B. Partitioning of nutrients during pregnancy and lactation: A review of mechanisms involving homeostasis and homeorhesis. Journal of Dairy Science, v.63, p.1415-1529, 1980.

BAUMRUCKER, C.R.; BLUM, J.W. Secretion of insulin-like growth factors in milk and their effect on the neonate. Livestock Production Science, v.35, p.49-72, 1993.

BAUMRUCKER, C.R.; BLUM, J.W. Effects of dietary recombinant human insulin-like growth factor-I on concentrations of hormones and growth factors in the blood of newborn calves. Journal of Endocrinology, v.140, p.15-21, 1994.

BAUMRUCKER, C.R.; HADSELL, D.L.; BLUM, J.W. Effects of dietary rhIGF-I in neonatal calves: II. Intestinal growth and IGF receptors. Journal of Animal Science, v.69, p.296, 1991. 
BAUMRUCKER, C.R.; HADSELL, D.L.; BLUM, J.W. Effects of dietary insulin growth factor I on growth and insulin like growth factor receptors in neonatal calf intestine. Journal of Animal Science, v.72, p.428-433, 1994.

BAXTER, R.C. Biochemical characterization if insulin-like growth factor binding proteins. Acta Endocrinologica, v.124, p.33-40, 1991.

BAXTER, R.C.; DAI, J. Purification and characterization of the acid-labile subunit of rat serum insulin-like growth-factor binding-protein complex. Endocrinology, v.134, p.848-852, 1994.

BESSER, T.E.; GAY, C.C.; PRITCHETT, L. Comparison of three methods of feeding colostrum to dairy calves. Journal of American Veterinary Medical Association, v.198, p.419-422, 1991.

BESSI, R.; PAULETTI, P.; d'ARCE, R.D.; MACHADO NETO, R. Absorção de anticorpos do colostro em bezerros. I. Estudo no intestino delgado proximal. Revista Brasileira de Zootecnia. v.31, p.2314 - 2324, 2002a.

BESSI, R.; PAULETTI, P.; d'ARCE, R.D.; MACHADO NETO, R. Absorção de anticorpos do colostro em bezerros. II. Estudo no intestino delgado distal. Revista Brasileira de Zootecnia. v.31, p.2325 - 2331, 2002b.

BLÄTTLER, U.; HAMMON, H.M.; MOREL, C.; PHILIPONA, C.; RAUPRICH, A.; ROMÉ, V.; HÜERON-LURON. I.; GUILLOTEAU, P.; BLUM, J.W. Feeding colostrum, its composition and feeding duration variably modify proliferation and morphology of the intestine and digestive enzyme activities of neonatal calves. Journal of Nutrition, v.131, p.1256-1263, 2001 
BLUM, J.W.; BAUMRUCKER, C.R. Colostral and milk insulin-like growth factor and related substances: Mammary gland and neonatal (intestinal and systemic) targets. Domestic Animal Endocrinology, v.23, p.101-110, 2002.

BLUM, F.W.; HAMMON, H. Endocrine and metabolic aspects in milk-fed calves. Domestic Animal Endocrinology, v. 17, p.219-230, 1999.

BRAMBELL, F.W.R. The passive immunity of the young mammal. Biological Reviews of the Cambridge Philosophical Society, v.33, p.488-531, 1958.

BREIER, B.H.; GLUCKMAN, P.D.; BASS, J.J. Plasma concentrations of insulinlike growth factor-I and insulin in the infant calf: ontogeny and influence of altered nutrition. Journal of Endocrinology, v.119, p.43-50, 1988.

BÜHLER, C.; HAMMON, H.; ROSSI, G.L.; BLUM, J.W. Small intestinal morphology in eight-day-old calves fed colostrum for different durations or only milk replacer and treated with Long-R3-insulin growth factor I and growth hormone. Journal of Animal Science, v.76, p.758-765, 1998.

BURRIN, D.G. Is milk-borne insulin-like growth factor-I essential for neonatal development? Journal of Nutrition, v.127, p.975S-979S, 1997.

BURRIN, D.G.; SHULMAN, R.J.; REEDS, P.J.; DAVIS, T.A.; GRAVITT, K.R. Porcine colostrum and milk stimulate visceral organ and skeletal muscle protein synthesis in neonatal piglets. Journal of Nutrition, v.122, p.12051213, 1992.

BURRIN, D.G.; DAVIS, T.A.; EBNER, S.; SCHOKNECHT, P.A.; FIOROTTO, M.L.; REEDS, P.J.; McAVOY, S. Nutrient-independent and nutrientdependent factors stimulate protein synthesis in colostrum-fed newborn pigs. Pediatric Research, v.37, p.593-599, 1995. 
BURRIN, D.J.; WESTER, T.J.; DAVIS, T.A.; AMICK, S.; HEATH, J.P. Orally administered IGF-I increases intestinal mucosal growth in formula-fed neonatal pigs. American Journal of Physiology, v.270, p.R1085-R1091, 1996.

BURTON, J.L.; McBRIDE, B.W.; BLOCK, E.; GLIMM, D.R.; KENNELLY, J.J. A review of bovine growth hormone. Canadian Journal of Animal Science, v.74, p.167-201, 1994.

BUTLER, A.A.; LEROITH, D. Minireview: tissue specific versus generalizes gene targeting of the IGF-I and IGF-IR genes and their roles in insulin-like growth factor physiology, Endocrinology, v.142, p.1685-1688, 2001.

BUTS, J.P.; KEYSER, D.; MARANDI, S.; MAERNOUDT, A.S.; SOKAL, E.M.; RAHYER, J.; HERMANS, D. Expression of insulin receptors and of 60-had receptor substrate in rat mature and immature enterocytes. American Journal of Physiology, v.273, p. G217-G226, 1997.

CARR, J.M.; OWENS, J.A.; GRANT, P.A.; WALTON, P.E.; OWENS P.C.; WALLACE, J.C. Circulating insulin-like growth factors (IGFs), IGF-binding proteins (IGFBPs) and tissue mRNA levels of IGFBP-2 and IGFBP-4 in the bovine feus. Journal of Endocrinology, v.145, p.545-557, 1995.

CLARK, R. The somatogenic hormones and insulin-like growth factor-1: Stimulators of lymphopoiesis and immune function. Endocrine Reviews, v.18, p.157-179, 1997.

CORDANO, P.; HAMMON, H.M.; MOREL, C.; ZURBRIGGEN, A.; BLUM, J.W. mRNA of insulin growth factor (IGF-I) quantification and presence of IGF-I binding proteins, and receptors for growth hormone, IGF-I and insulin, determined by reverse transcribed polymerase chain reaction, in the liver of 
growing and mature male cattle. Domestic Animal Endocrinology, v.19, p.191-208, 2000.

DAHLY, E.M.; GUO, Z.W.; NEY, D.M. Alterations in enterocyte proliferation and apoptosis accompany TPN-induced mucosal hypoplasia and IGF-I-induced hyperplasia in rats. Journal of Nutrition, v.132, p.2010-2014, 2002.

DAI, J.; BAXTER, R.C. Regulation in vivo of the acid-labile subunit of the rat serum insulin-like growth factor-binding protein complex. Endocrinology, v.135, p.2335-2341, 1994.

DAVIS, T.A.; BURRIN, D.G.; FIOROTTO, M.L.; NGUYEN, H.V. Skeletal muscle and jejunal protein synthesis is more responsive to feeding in 7- than in 26day old pigs. American Journal of Physiology, v.270, p.E802-809, 1996.

DONOVAN, S.M.; McNEIL, L.K.; JIMÉNEZ-FLORES, R.; ODLE, J. Insulin-like growth factors and insulin-like growth factor binding proteins in porcine serum and milk throughout lactation. Pediatric Research, v.36, p.159-168, 1994.

DONOVAN, S.M.; CHAO, J.C.J.; ZIJLSTRA, R.T.; ODLE, J. Orally administered iodinated recombinant human insulin-like growth factor-I (I ${ }^{125}$-rhlGF-I) is poorly absorbed by the newborn piglet. Journal of Pediatric Gastroenterology and Nutrition, v.24, p.174-182, 1997.

GEORGIEV, I.P.; GEORGIEVA, T.M.; PFAFFL, M.; HAMMON, H.M.; BLUM, J.W. Insulin-like growth factor and insulin receptors in intestinal mucosa of neonatal calves. Journal of Endocrinology, v.176, p.121-132, 2003.

GEORGIEVA, T.M.; GEORGIEV, I.P.; ONTSOUKA, E.; HAMMON, H.M.; PFAFFL, M.; BLUM, J.W. Abundance of message for insulin-like growth factors-I and II and for receptors for growth hormone, insulin-like growth factors-I and II, and insulin in the intestine and liver of pre-and full term calves. Journal of Animal Science, v.81, 2294-2300, 2003. 
GIBSON, U.E.M.; HEID, C.A.; WILLIAMS, P.M. A novel method for real time quantitative RT-PCR. Genome Research, v.6, p.995-1001, 1996.

GROSVENOR, C.E.; PICCIANO, M.F.; BAUMRUCKER, C.R. Hormones and growth factors in milk. Endocrine Reviews, v.14, p.710-728, 1993.

HADSELL, D.L.; BAUMRUCKER, C.R.; KESINGER, R.S. Effects of elevated blood insulin-like growth factor-i (IGF-I) concentration upon IGF-I in bovine mammary secretions during the colostrum phase. Journal of Endocrinology, v.137, p.223-230, 1993.

HAMMON, H.; BLUM, J.W. The somatotropic axis in neonatal calves can be modulated by nutrition, growth hormone and Long-R3-IGF-I. American Journal of Physiology, v.273, E130-138, 1997.

HAMMON H.M.; BLUM, J.W. Feeding different amounts of colostrum or only milk replacer modify receptors of intestinal insulin-like growth factors and insulin in neonatal calves. Domestic Animal Endocrinology, v.22, p. 155168, 2002.

HARREL, R.J.; THOMAS, M.J.; BOYD, R.D.; CZERWINSKI, S.M.; STEELE, N.C.; BAUMAN, D.E. Ontogenic maturation of the somatotropin/insulin-like growth factor axis. Journal of Animal Science, v.77, p.2934-2941, 1999.

HEINZ-ERIAN, P.; KESSLER, U.; FUNK, B.; GAIS, P.; KIESS, W.; Identification and in situ localization of the insulin-like growth factor-II/mannose-6phosphate (IGF-II/M6P) receptor in the rat gastrointestinal tract: comparison with the IGF-I receptor. Endocrinology, v.129, p.1769-1778, 1991.

HERNADEZ-SANCHEZ, C.; WERNER, H.; ROBERTS, C.T.; WOO, E.J.; HUM, D.W.; ROSENTHAL, S.M. Differential regulation of insulin-like growth factor-I (IGF-I) receptor gene expression by IGF-I and basic fibroblastic growth factor. Journal of Biological Chemistry, v.272, p.4663-4670, 1997. 
HOLMAN, S.R.; BAXTER, R.C. Insulin-like growth factor binding protein-3 factors binary and ternary complex-formation. Growth Regulation, v.6, p.4250,1996

HOSSNER, K.L.; McCUSKER, R,H.; DODSON, M.V. Insulin-like growth factors and their binding proteins in domestic animals. Animal Science, v.64, p.115, 1997.

HOULE, V.M.; SCHROEDER, E.A.; ODLE, J.; DONOVAN, S.M. Small intestinal dissaccharidases activity and ileal villus height are increased in piglets consuming formula containing recombinant human insulin-like growth factor-I. Pediatric Research, v.42, p. 78-86, 1997.

JEHLE, P.M.; FUSSGAENGER, R.D.; ANGELUS, N.K.; JUNGWIRTH, R.J.; SAILE, B.; LUTZ, M.P. Proinsulin stimulates growth of small intestinal cryptlike cells acting via specific receptors. American Journal of Physiology, v.276, p.E262-268, 1999.

JOCHIMS, K.; KAUP, F.J.; DROMMER, W. Immunoelectron microscopic demonstration of the absorption of colostral igg by small-intestinal enterocytes in newborn rats. Research in Veterinary Science, v.57, p.146-151, 1994.

JONES, J.I.; CLEMMONS, D.R. Insulin-like growth factors and their binding proteins: Biological actions. Endocrine Reviews, v.16, p.3-34, 1995.

KIKUCHI, K.; BICHELL; D.P.; ROTWEIN, P. Chromatin changes accompany the developmental activation of insulin-like growth factor I gene transcription. Journal of Biological Chemistry, v.267, p.21505-21511, 1992.

KÜHNE, S.; HAMMON, H.M.; BRUCKMAIER, R.M.; MOREL, C.; ZBINDEN, Y.; BLUM, J.W. Growth performance, metabolic and endocrine traits, and absorptive capacity in neonatal calves fed either colostrum or milk replacer at two levels. Journal of Animal Science, v.78, p.609-620, 2000. 
LABARCA, C.; PAIGEN, K. A simple, rapid, and sensitive DNA assay procedure. Analitic Biochemistry, v.102, p.344-352, 1980.

LABURTHEM. M.; ROUYER-FESSARD, C.; CAMMELTOFT, S. Receptors for insulin-like growth factors I and II in rat gastrointestinal epithelium. American Journal of Physiology, v.254, p.G457-G462, 1988.

LECCE, J.G. Effect of dietary regimen on cessation of uptake of macromolecules by piglet intestinal epithelium (closure) and transport to blood. Journal of Nutrition, v.103, p.751-756, 1973.

LECCE, J.G.; MORGAN, D.O. Effect of dietary regimen on cessation of intestinal absorption of large molecules (closure) in neonatal pig and lamb. Journal of Nutrition, v.78, p.263-268, 1962.

LEE, C.Y.; CHUNG, C.S.; SIMMEN, F.A. Ontogeny of the porcine insulin-like growth factor system. Molecular and Cellular Endocrinology, v.93, p.7180, 1993.

LEE, C.Y.; BAZER, F.W.; ETHERTON, T.D.; SIMMEN, F.A. Ontogeny of insulin like growth factors (IGF-I and IGF-II) and IGF-binding proteins in porcine serum during fetal and postnatal development. Endocrinology, v.128, p.2336-2344, 1991.

LeROITH, D.L. Insulin-like growth factor. Hormone and Metabolic Research, v.31, p.41-42, 1999.

LeROITH, D.; SAMPSON, P.C.; ROBERTS, C.T. How does the mitogenic insulin-like growth factor I receptor differ from the metabolic insulin receptor? Hormone Research, v.41, p.74-79 (suppl.2), 1994.

LeROITH, D.; SCAVO, L.; BUTLER, A. What is the role of circulating IGF-I? Trends in Endocrinology \& Metabolism, v.12, p.48-52, 2001. 
LeROITH, D.; WERNER, H.; BEITNER-JOHNSON, D.; ROBERTS, C.T. Molecular and cellular aspects of the insulin-like growth factor I receptor. Endocrine Reviews, v.16, p.143-163, 1995.

LOUVEAU, I.; DAUNCEY, M.J.; DIVIDICH, J. Regulation and development by nutrition and by the somatotropic and thyroid axes in the neonatal pig. Livestock Production Science, v.66, p.121-131, 2000.

LOWE, W.L.; ROBERTS, C.T.; LASKY, S.R.; LeROITH, D. Differential expression of alternative 5'untranslated regions in mRNAs encoding rat insulin-like growth factor I. Proceedings of the National Academy of Sciences of the USA, v.84, p.8946-8950, 1987.

LOWRY, O.H.; ROSENBROUGH, N.J.; FARR, A.L.; RANDALL, R.J. Protein measurement with Folin phenol reagent. Journal of Biological Chemistry, v.193, p.256-275,1951.

LUND, P.K. Insulin-like growth factor I: Molecular biology and relevance to tissue-specific expression and action. Recent Progress in Hormone Research, v.49, p.125-148, 1994.

MA, L.; XU, R.J. Oral insulin-like growth factors-I stimulates intestinal enzyme maturation in newborn rats. Life Sciences, v.61, p.51-58, 1997.

MACDONALD, R.S. The role of insulin-like growth factors in small intestinal cell growth and development. Hormone Metabolism Research, v.31, p.103113, 1999.

MATTERI, R.L.; BYER, C.J.; TOUCHETTE, K.J.; CARROL, J.A.; ALLEE, G.L. Effects of weaning on somatotrophic gene expression and circulating levels of insulin-like growth factor-1 (IGF-I) and IGF-2 in pigs. Domestic Animal Endocrinology, v.19, p.247-259, 2000. 
McCUSKER, R.H. Controlling insulin-like growth factor activity and the modulation of insulin-like growth factor binding protein and receptor binding. Journal of Dairy Science, v.81, p.1790-1800, 1998.

McGUIRE, M.A.; DWYER, D.A.; HARRELL, R.J.; BAUMAN, D.E. Insulin regulates circulating insulin-like growth factors and some of their binding proteins in lactating cows. American Journal of Physiology, v.32, p.723730, 1995.

McMULLEN, S.; WATHES, D.C. Acute nutrient restriction during mid-pregnancy in the ewe: responses and consequences. Proceedings of a Workshop on Embryonic and Fetal Nutrition, v.10, p.45-48, 2003.

MORGAN, C.J.; COUTTS, A.G.P.; McFADYEN, M.C.; KING, T.P.; KELLY, D. Characterization of IGF-I receptors in the porcine small intestine during postnatal development. Nutritional Biochemistry, v.7, p.339-347, 1996.

MURPHY, L.J.; BELL, G.I.; FRIESEN, H.G. Tissue distribution of insulin-like growth factor I and II messenger ribonucleic acid in the adult rat. Endocrinology, v.120, p.1279-1282, 1987.

MYLONAS, P.G.; MATSOUKA, P.T.; PAPANDONIOU, E.V.; VAGIANOS, C.; KALFARENTZOS, F.; ALEXANDRIDES, T.K. Growth hormone and insulinlike growth factor I protect intestinal cells from radiation induced apoptosis. Molecular and Cellular Endocrinology, v.160, p.115-122, 2000.

NEY, M.D.; HUSS, D.J.; GILLINGHAM, M.B.; KRITSCH, K.R.; DAHLY, E.M.; TALAMANTEZ, J.L.; ADAMO, M.L. Investigation of insulin-like growth factor (IGF)-I and insulin receptor binding and expression in jejunum of parenterally fed rats treated with IGF-I or growth hormone. Endocrinology, v.140, p.4850-4860, 1999. 
ODLE, J.; ZIJLSTRA, R.T.; DONOVAN, S.M. Intestinal effects of milkborne growth factors in neonates of agricultural importance. Journal of Animal Science, v.74, p.2509-2522, 1996.

ONTSOUKA, C.E.; SAUTER, S.N.; BLUM, J.W.; HAMMON, H.M. Effects of colostrum feeding and dexamethasone treatment on mRNA levels of insulinlike growth factors (IGF)-I and -II, IGF binding proteins-2 and -3, and on receptors for growth hormone, IGF-I, IGF-II, and insulin in the gastrointestinal tract of neonatal calves. Domestic Animal Endocrinology, v.26, p.155-175, 2004.

OSGERBY, J.C.; WATHES, D.C.; HOWARD, D.; GADD, T.S. The effect of maternal undernutrition on ovine fetal growth. Journal of Endocrinology, v.173, p.131-141, 2002.

PAKKANEN, R.; AALTO, J. Growth factors and antimicrobial factors of bovine colostrum. International Dairy Journal, v.7, p.285-297, 1997.

PATUREAU-MIRAND, P.; MOSONI, L.; LEVEUX, D.; ATTAIX, D.; BONNET, Y. Effect of colostrum feeding on protein metabolism in the small intestine of newborn lambs. Biology of Neonate, v. 57, p.30-36, 1990.

PAULETTI, P. Fator de crescimento semelhante à insulina I durante a formação e transferência de imunidade passiva para bezerros recémnascidos. Piracicaba, 2003. 123p. Tese (Doutorado) - Escola Superior de Agricultura "Luiz de Queiroz", Universidade de São Paulo.

PELL, J.M. Regulation of insulin-like growth factor I bioavailability in growing animals. Journal of Animal Science, v.75, suppl.2, p.20-31, 1997. 
PELL, J.M.; SAUNDERS, J.C.; GILMOUR. Differential regulation of transcription initiation from insulin-like growth factor-I (IGF-I) leader exons and of tissue IGF-I expression in response to changed growth hormone and nutritional status in sheep. Endocrinology, v.132, p.1797-1807, 1993.

PETERSON, C.A.; CAREY, H.V.; HINTON, P.L.; LO, H.C.; NEY, D.M. GH elevates serum IGF-I levels but does not alter mucosal atrophy in parenterally fed rats. American Journal of Physiology-Gastrointestinal and Liver Physiology, v.272, p.G1100-G1108, 1997.

PFAFFL, M. Development and validation of an externally standardized quantitative insulin-like growth factor-1 RT-PCR using LightCycler SYBR Green Technology. Biochemica, n.3, p.13-16, 2000.

PFAFFL, M.W.; GEORGIEVA, T.M.; GEORGIEV, I.P.; ONTSOUKA, E.; HAGELEIT, M.; BLUM, J.W. Real-time RT-PCR quantification of insulin-like growth factos (IGF)-I, IGF-I receptor, IGF-II, IGF-II receptor, insulin receptor, growth hormone receptor, IGF-binding proteins 1, 2 and 3 in bovine species. Domestic Animal Endocrinology, v.22, p.91-102, 2002.

PHILLIPS, L.S.; KAYTOR, E.N. Metabolic regulation of IGF-I gene expression. Journal of Animal Science, v.77 (suppl.3), p.43-54, 1999.

PLAYFORD, R.J.; MACDONALD, C.E.; JOHNSON, W.S. Colostrum and milkderived peptide growth factors for the treatment of gastrointestinal disorders. American Journal of Clinical Nutrition, v.72, p.5-14, 2000.

POTTEN, C.S.; BOOTH, C.; PRITCHARD, D.M. The intestinal epithelial stem cell: the mucosal governor. International Journal of Experimental Pathology, v.78, p.219-243, 1997. 
QUIGLEY, J.D.; MARTIN, K.R.; DOWLEN, H.H. Concentrations of trypsin inhibitor and immunoglobulins in colostrum of Jersey cows. Journal of Dairy Science, v.78, p.1573-1577, 1995.

RAUPRICH, A.B.E.; HAMMON, H.M.; BLUM, J.W. Influence of feeding different amounts of first colostrum on metabolic, endocrine, and health status and on growth performance in neonatal calves. Journal of Animal Science, v.78, p.896-908, 2000.

RHOADS, J.M.; CHEN, W.; CHU, P.; BERSCHNEIDER, H.M.; ARGENZIO, R.A.; PARADISO, A.M. L-glutamine and L-asparagine stimulate $\mathrm{Na}+-\mathrm{H}+$ exchange in porcine jejunal enterocytes. American Journal of Physiology, v.266, p.G828-838, 1994.

ROFFLER, B.; FÄH, A.; SAUTER, S.N.; HAMMON, H.M.; GALLMANN, P.; BREM, G.; BLUM, J.W. Intestinal morphology, epithelial cell proliferation, and absorptive capacity in neonatal calves fed milk-born insulin-like growth factorI or a colostrum extract. Journal of Dairy Science, v.86, p.1797-1806, 2003.

ROTWEIN, P.; POLLOCK, K.M.; DIDIER, D.K.; KRIVI, G.G. Organization and sequence of the human insulin-like growth factor I gene. Alternative RNA processing produces two insulin-like growth factor I precursor peptides. Journal of Biology Chemistry, v.15, p.4828-4832, 1986.

SAS INSTITUTE. SAS/STAT: user's guide; release 6.08 ed. Cary, 1991. $1028 p$.

SCHOEBER, D.A.; SIMMEN, F.A.; HADSELL, D.L.; BAUMRUCKER, C.R. Perinatal expression of type I IGF receptors in porcine small intestine. Endocrinology, v.126, p.1125-1132, 1990. 
SEJRSEN, K.; PEDERSEN, L.O. VESTERGAARD, M.; PURUP, S. Biological activity of bovine milk. Contribution of IGF-I and IGF binding proteins. Livestock Production Science, v.70, p.79-85, 2001.

SIMMEN, F.A.; SIMMEN, R.C.M.; REINHART, G. Maternal and neonatal somatomedin C/insulin-like growth factor-I (IGF-I) and IGF biding proteins during early lactation in the pig. Developmental Biology, v.130, p.16-27, 1988.

SIMMEN, F.A.; CERA, K.R.; MAHAN, D.C. Stimulation by colostrum or mature milk of gastrointestinal tissue development in newborn pigs. Journal of Animal Science, v.68, p.3596-3603, 1990.

SJÖGREN, K.; LIU, J.; BLAD, K.; SKRTIC, S.; VIDAL, O.; WALLENIUS, V.; LeROITH, D.; TÖRNELL, J.; ISAKSSON, O.G.P.; JANSSON, J.O.; OHLSSON, C. Liver derived insulin-like growth factor I (IGF-I) is the principal source of IGF-I in blood but is not required for postnatal body growth in mice. Proceedings of National Acadamy of Sciences of the USA, v.96, p.70887092, 1999.

SMEATON, T.C.; SIMPSON-MORGAN, M.W. Epithelial cell renewal and antibody transfer in the intestine of the fetal and neonatal lamb. Australian Journal of Experimental Biological Science, v.63, p.41-51, 1985.

STEEB, C.B.; TRAHAIR, J.F.; TOMAS, F.M.; READ, L.C. Prolonged administration of IGF-I peptides enhances growth of gastrointestinal tissues in normal rats. American Journal of Physiology, v.266, p.G1090-1098, 1994.

STEWART, C.E.H.; ROTWEIN, P. Growth, differentiation, and survival: multiple physiological functions for insulin-like growth factors. Physiological Reviews, v.76, p.1005-1026, 1996. 
SWORDS, W.E.; WU, C.C.; CHAMPLIN, F.R.; BUDDINGTON, R.K. Postnatal changes in selected bacterial groups of the pig colonic microflora. Biololgy Neonate, v.63, p.191-200, 1993.

TERMANINI, B.; NARDI, R.V.; FINAN, T.M.; PARIKH, I.; KORMAN, L.Y. Insulinlike growth factor I receptor in rabbits gastrointestinal tract. Characterization and auto radiographic localization. Gastroenterology, v.99, p.51-60, 1990.

THISSEN, J.P.; KETELSLEGERS, J.M.; UNDERWOOD, L.E. Nutritional regulation of the insulin-like growth factors. Endocrine Reviews, v.15, p.80101, 1994.

VACHER, P.Y.; BESTETTI, G.; BLUM, J.W. Insulin-like growth factor I absorption in the jejunum of neonatal calves. Biology of the Neonate, v.68, p.354-367, 1995.

VEGA, J.R.; GIBSON, C.A.; SKAAR, T.C.; HADSELL, D.L.; BAUMRUCKER, C.R. Insulin-like growth factor (IGF)-I and II and IGF binding proteins in serum and mammary secretions during the dry period and early lactation in dairy cows. Journal of Animal Science, v.69, p.2538-2547, 1991.

WATCHES, D.C.; REYNOLDS, T.S.; ROBINSON, R.S.; STEVENSON, K.R. Role of the insulin-like growth factor system in uterine function and placental development in ruminants. Journal of Dairy Science, v. 81, p.1778-1789, 1998.

WERNER H.; BAXH, M.A.; STANNARD, B.; ROBERTS, C.T.; LeROITH, D. Structural amd functional analysis of the insulin-like growth factor I receptor gene promotes. Molecular Endocrinology, v.6, p. 1545-1558, 1992.

WESTER, T.J.; FIOROTTO, M.L.; KLINDT, J.; BURRIN, D.G. Feeding colostrum increases circulating insulin-like growth factor I in newborn pigs 
independent of endogenous growth hormone secretion. Journal of Animal Science, v.76, 3003-3009, 1998.

WINESETT, D.E.; ULSHEN, M.H.; HOYT, E.C.; MAHAPATRA, N.K.; FULLER, C.R.; LIND, P.K. Regulation and localization of the insulin-like growth factor system in small bowel during altered nutrient status. American Journal of Physiology, v.268, p.G631-G640, 1995.

XU, R.J.; MELLOR, D.J.; BIRTLES, M.J.; BREIER, B.H. Effects of oral IGF-I or IGF-II on digestive organ growth in newborn piglets. Biology of Neonate, v.66, p.280-287, 1994.

YOUNG, G.P.; TARANTO, T.M.; JONAS, H.A.; COX, A.J.; HOGG, A.; WERTHER, G.A. Insulin-like growth factors and the developing and mature rat small intestine: receptors and biological actions. Digestion, v.46, p.240252, 1990.

ZHANG W.; THORNTON, W.H.; MacDONALD, R.S. Insulin-like growth factor-I and II receptor expression in rat colon mucosa are affected by dietary intake. Journal of Nutrition, v.128, p.158-165, 1998.

ZHANG, H.; MALO, C.; BUDDINGTON, R.K. Suckling induces rapid intestinal growth and changes in brush border digestive functions of newborn pigs. Journal of Nutrition, v.127, p.418-426, 1997. 